\title{
La utilización de materiales biológicos humanos con fines diagnósticos y terapéuticos*
}

\author{
Sergio Romeo Malanda \\ Investigador doctor del Centro de Derecho y Genética \\ Universidad de Tasmania (Hobart, Australia)
}

Recibido: 01.12 .07

Aceptado: 21.12.07

Resumen: Los materiales biológicos humanos se utilizan en la actualidad para un gran número de fines. En este trabajo vamos a ocuparnos de aquellos que menos rechazo plantean desde un punto de vista social, pero que, sin embargo, presentan interesantes cuestiones de carácter ético y jurídico. Por un lado, diversos materiales biológicos se utilizan diariamente para la realización de análisis médicos, con la intención de evaluar la salud presente o futura del paciente. Por otra parte, algunos materiales biológicos pueden ser empleados con fines terapéuticos en el propio sujeto o en terceros, como sucede en el caso de los trasplantes de órganos y tejidos. El autor analiza la extensa legislación existente al respecto en relación con la obtención, utilización y almacenamiento de dichos materiales biológi$\cos$.

Palabras clave: materiales biológicos humanos, diagnósticos médicos, biobancos, trasplantes de órganos, bancos de cordón umbilical, donación de sangre, tejidos fetales.

Abstract: At present times human biological materials are used for a great number of purposes. In this work we are going to deal with those that raise less conflict from a social point of view, but that, nevertheless, present interesting ethical and legal issues. On the one hand, diverse biological materials are used every day to carry out medical analyses, with the intention of testing the present or future health of the patient. On the other hand, some biological materials can be used for therapeutic purposes in the own subject or in a third person. That is the case of organ and tissue transplantation. The author analyses the extensive legislation existing in this topic in relation with the obtaining, use and storage of the above mentioned biological materials.

Key words: human biological material, medical diagnosis, biobanks, organ transplantation, umbilical cords banks, blood donation, foetal tissues.

* Este trabajo se enmarca dentro del proyecto de investigación «Implicaciones jurídicas de la utilización de materiales biológicos humanas y biobancos en investigación científica», con referencia HU2003-22, subvencionado por el Departamento de Educación, Universidades e Investigación del Gobierno Vasco (2005-2007), cuyo investigador principal es el profesor Carlos María Romeo Casabona. 
Sumario: 1. Introducción. - 2. Tratamiento de materiales biológicos con fines diagnósticos. 2.1. La relevancia de los materiales biológicos con fines diagnósticos. 2.2. Una cuestión previa: la distinción entre el consentimiento para la obtención y el consentimiento para el uso posterior del material biológico. 2.3. La obtención de materiales biológicos con fines diagnósticos. 2.4. La utilización de materiales biológicos con fines diagnósticos. 2.5. El almacenamiento de materiales biológicos con fines diagnósticos.-3. El tratamiento de materiales biológicos con fines terapéuticos. 3.1. La relevancia de los materiales biológicos con fines terapéuticos. 3.2. La obtención de materiales biológicos con fines terapéuticos. 3.2.1. Fines terapéuticos para el sujeto fuente. 3.2.2. Fines terapéuticos para terceros. 3.2.2.1. La donación de órganos. 3.2.2.2. La donación de células y tejidos. 3.2.2.3. La donación de sangre. 3.2.2.4. La donación de material fetal. 3.3. Utilización de materiales biológicos con fines terapéuticos. Requisitos respecto al receptor. 3.4. El almacenamiento de materiales biológicos con fines terapéuticos (I): bancos de sangre y tejidos. 3.5. El almacenamiento de materiales biológicos con fines terapéuticos (II): los bancos de cordón umbilical.

\section{INTRODUCCIÓN}

Aunque en la actualidad se está prestando una especial atención a la utilización de materiales biológicos con fines de investigación biomédica, lo cierto es que sus potenciales usos son extremadamente variados ${ }^{1}$.

Por material biológico puede entenderse cualquier sustancia biológica que contenga ácidos nucleicos de origen humano. De esta forma, el concepto de material biológico abarca realidades tan variadas como las células, los tejidos («todas las partes constituyentes del cuerpo humano formado por células») ${ }^{2}$ o los órganos («parte diferenciada y vital del cuerpo humano formada por diferentes tejidos, que mantiene su estructura, vascularización y capacidad para desarrollar funciones fisiológicas con un nivel de autonomía importante») $)^{3}$. También se incluirían los gametos humanos.

Sin embargo, quedan excluidos del concepto de material biológico, y por lo tanto del ámbito de estudio de este trabajo, los individuos humanos, pues los materiales biológicos son sustancias separadas del cuerpo humano. A

${ }^{1}$ Vid. una exposición general sobre esta cuestión, IRISH COUNCIL FOR BIOETHICS, Recommendations on the collection, use and storage of human biological material in research (2005), Capítulo I.

${ }^{2}$ Cfr. art. 3.b) de la Directiva 2004/23/CE de 31 de marzo de 2004, relativa al establecimiento de normas de calidad y de seguridad para la donación, la obtención, la evaluación, el procesamiento, la preservación, el almacenamiento y la distribución de células y tejidos humanos.

${ }^{3}$ Cfr. art. 3.e) Directiva 2004/23/CE. 
este respecto, por individuo humano se entiende tanto al ser humano nacido (la persona), como al embrión y al feto. Sí entran dentro del estudio, sin embargo, las células o tejidos que puedan extraerse de ellos.

Muchos de los usos potenciales de dichos materiales, como es el caso de los trasplantes, tienen beneficios incuestionables, pero el uso diverso de materiales biológicos humanos también plantea nuevos dilemas éticos y nuevas cuestiones jurídicas. En cualquier caso, los principales problemas de carácter ético y jurídico son comunes a todos los usos, aunque puedan plantearse ciertas cuestiones específicas en relación con alguno de ellos. Además, en muchas ocasiones, diferentes usos pueden estar interrelacionados.

El tipo de materiales biológicos requeridos variará dependiendo del uso que se les asigne. A veces será necesario un órgano completo, o parte de él, o una cierta cantidad de sangre. En lugar de eso, podría bastar con una pequeña cantidad de tejido, unas pocas células o incluso componentes subcelulares.

Probablemente, el uso más común y extendido de los materiales biológicos es el de diagnóstico y tratamiento de enfermedades. Por ejemplo, sangre o tejidos procedentes de una biopsia obtenidos de pacientes para poder realizar el oportuno examen diagnóstico. O líquido amniótico obtenido durante el embarazo para realizar una análisis genético prenatal. Ello plantea interesantes cuestiones éticas y jurídicas, como las relativas a la posible comercialización de tales materiales o a la confidencialidad sobre la identidad de los donantes y la información obtenida de los resultados de los análisis, etc., lo cual requiere provisiones epecíficas en la obtención, identificación y acceso a los materiales biológicos obtenidas tanto ante mortem como post mortem.

Es indudable que la sociedad demanda con carácter general un cierto respeto al cuerpo humano y sus partes. Por ello, los materiales biológicos no deberían usarse de cualquier forma. No obstante, hay situaciones en las que la gran mayoría de las personas están dispuestas aceptar la utilización de materiales biológicos humanos, siempre que se respeten algunos requisitos. Para ello, es necesario establecer ciertos principios éticos y ciertas reglas jurídicas que determinen cuándo, y con qué propósitos, el cuerpo humano y sus partes pueden ser utilizados.

En cualquier caso, no es posible aquí hacer un estudio detallado en extremo, por lo que únicamente haré alusión a los principales textos legales aplicables a cada caso, haciendo referencia a las cuestiones jurídicas más relevantes que se suscitan en relación con el tratamiento de materiales biológi$\cos ^{4}$, esto es, su obtención, utilización y almacenamiento, dependiendo de

${ }^{4}$ Utilizamos aquí el término «tratamiento» en el sentido previsto en la Ley 14/2007, de 3 de julio, de Investigación Biomédica (LIB) para los materiales biológicos. En el art. 3.w) LIB se define tratamiento de muestras biológica como aquellas «operaciones y procedimientos que permitan la obtención, conservación, utilización y cesión de (...) materiales biológicos». 
cuál sea el fin pretendido. En concreto, me ocuparé de los requisitos, tanto personales (esencialmente, los relativos a la capacidad del sujeto fuente) ${ }^{5}$ como formales (contenido de la información requerida, intervención de terceros, plazos, etc.), exigidos por la ley para dicho tratamiento.

\section{TRATAMIENTO DE MATERIALES BIOLÓGICOS CON FINES DIAGNÓSTICOS}

\subsection{La relevancia de los materiales biológicos con fines diagnósticos}

El uso de materiales biológicos con fines diagnósticos es muy común en la asistencia sanitaria cotidiana, y puede producirse en varios momentos y con diversas finalidades: detectar una enfermedad, comprobar su evolución o respuesta al tratamiento, así como su posible remisión, etc. De igual manera, pueden ser empleadas tanto para detectar enfermedades cuyos efectos son actuales, como para realizar prognosis sobre la salud del paciente, especialmente cuando se realizan análisis genéticos que permiten valorar la mayor o menor probabilidad de un sujeto de llegar a padecer una enfermedad determinada, o si se encuentra en grupo de riesgo. Por ejemplo, mujeres portadoras de los genes BRCA 1 y BRCA 2, genes de enfermedades monogénicas (Huntington, fibrosis quística, talasemia, etc.), cromosomopatías (síndrome de Down). De esta forma, puede comenzarse un tratamiento (preventivo o paliativo), de ser ello posible, o asesorar al paciente sobre las formas de prevenir riesgos que puedan hacer aparecer la enfermedad, hacer un seguimiento de su salud para detectar los primeros síntomas y poder comenzar un tratamiento a tiempo, o incluso permitir a los sujetos afectados tomar decisiones sobre su futura descendencia, $u$ otro tipo de decisiones.

Los materiales biológicos empleados con este fin pueden ser muy variadas. Probablemente el más común sea la muestra de sangre, pero en otros casos puede ser necesario obtener tejidos. Así sucede con las biopsias, en las que pueden obtener grandes cantidades de tejidos o, incluso, secciones de órganos.

\subsection{Una cuestión previa: la distinción entre el consentimiento para la obtención y el consentimiento para el uso posterior del material bio- lógico}

Antes de destinar un material biológico al uso pretendido hay que obtenerlo. Para ello el sujeto fuente debe, con carácter general, dar su consenti-

${ }^{5}$ Por sujeto fuente se entiende, de acuerdo con lo dispuesto en el art. 3.v) LIB, el «individuo vivo, cualquiera que sea su estado de salud, o fallecido del que proviene la muestra biológica». 
miento, y tiene que ser informado de ciertos elementos. De este modo, como dice ROMEO CASABONA, «el consentimiento debe abarcar entonces una doble vertiente: el acto principal (participar en un ensayo, someterse a una intervención quirúrgica) y el seguro o posible uso de la muestra biológica» ${ }^{6}$.

Por supuesto, en la mayoría de los casos la obtención de la muestra no puede desligarse, de su uso posterior. La muestra se obtiene para algo en concreto. Y el sujeto fuente debe conocer también esa finalidad. Pero, sin embargo, ello no elimina el hecho de que el acto de obtención y los actos de utilización posterior son dos realidades diferentes que conviene distinguir, pues también son dos los consentimientos que se prestan y dos las informaciones que el sujeto fuente debe recibir, y ello aunque ambos consentimientos se presten conjuntamente y la información se reciba de forma completa en un mismo acto.

Además, también hay que tener en cuenta que, en muchas ocasiones, la muestra se obtiene con una finalidad directa, pero se plantea la posibilidad de usos secundarios. En tales casos, el consentimiento para dichos usos está desligado de la obtención de la muestra y se prestará de forma independiente aunque, de nuevo, si tales usos son ya conocidos en el momento de la obtención, el consentimiento para un uso posterior o secundario pueda prestarse conjuntamente con el del fin principal ${ }^{7}$.

En realidad, como se verá a lo largo de este trabajo, el fin principal al cual desea destinarse el material biológico en cuestión es esencial para el otorgamiento del consentimiento, hasta el punto de que de ello dependerá su validez, y que la muestra pueda o no obtenerse. Por ello, cuando hagamos referencia a los requisitos para la obtención de la muestra, nos referimos a los requisitos personales y formales para poder consentir su obtención. Por su parte, la cuestión relativa a la información sobre los usos posteriores a la obtención se trata en el apartado correspondiente relativo al uso de los materiales biológicos.

\footnotetext{
${ }^{6}$ Carlos María Romeo Casabona, «Utilización de materiales biológicos y bancos para la investigación biomédica», IV Congreso Mundial de Bioética. Ponencias y comunicaciones, Sociedad Internacional de Bioética, Gijón, 2005, p. 89.

${ }^{7}$ Según el art. 58.2 LIB «el consentimiento del sujeto fuente será siempre necesario cuando se pretendan utilizar con fines de investigación biomédica materiales biológicos que hayan sido obtenidas con una finalidad distinta, se proceda o no a su anonimización». Y el art. 60.1 LIB dispone que dicho consentimiento deberá otorgarse bien en el acto de obtención de la muestra (si el uso secundario era ya conocido en ese momento), bien con posterioridad, de forma específica para una investigación concreta (cuando el nuevo destino de la muestra es sobrevenido). En ambos casos, el art. 59 recoge la información previa que hay que comunicar al sujeto fuente antes de la utilización del material biológico.
} 


\subsection{La obtención de materiales biológicos con fines diagnósticos}

En principio, la obtención de materiales biológicos con fines de diagnóstico médico se regirá por lo dispuesto en la Ley 41/2002, de 14 noviembre, básica reguladora de la autonomía del paciente y de derechos y obligaciones en materia de información y documentación clínica (LAP), la cual recoge con carácter general su art. 2.2 que «toda actuación en el ámbito de la sanidad requiere, con carácter general, el previo consentimiento de los pacientes o usuarios». Por su parte, el art. 3 LAP define intervención en el ámbito de la sanidad como «toda actuación realizada con fines preventivos, diagnósti$\cos$, terapéuticos, rehabilitadores o de investigación».

En definitiva, no existe ninguna duda acerca de la aplicabilidad de la LAP a los actos de obtención de materiales biológicos con fines diagnósticos. De este modo, de acuerdo con lo establecido en el mencionado art. 2.2, con anterioridad a la extracción del material biológico que sirve para realizar el diagnóstico, el sujeto fuente deberá consentirlo, tras recibir una información «adecuada» sobre el alcance del procedimiento empleado, información que deberá ser más rigurosa, evidentemente, cuando se trate de un procedimiento invasivo (por ejemplo, la extracción de sangre o la práctica de una biopsia).

Dos son las principales cuestiones que regula esta Ley y que deben ser ahora referidas: el consentimiento del sujeto fuente y la información requerida previa a dicho consentimiento.

Por lo que respecta al consentimiento, el art. 8 LAP establece que toda actuación en el ámbito de la salud de un paciente (por lo tanto, como hemos dicho, también con fines diagnósticos) necesita el consentimiento libre y voluntario del afectado, una vez que, recibida la información necesaria, haya valorado las opciones propias del caso.

Como regla general, el consentimiento será otorgado de forma verbal. Sin embargo, deberá prestarse por escrito cuando se trate de un procedimiento diagnóstico invasivo y, en general, cuando se apliquen procedimientos que supongan riesgos o inconvenientes de notoria y previsible repercusión negativa sobre la salud del paciente (art. 8.2 LAP). Ahora bien, esta disposición no puede entenderse en el sentido de que toda obtención de materiales biológicos aplicando técnicas invasivas requerirá siempre y en todo caso un consentimiento escrito, sino únicamente cuando ello suponga «riesgos o inconvenientes de notoria y previsible repercusión negativa sobre la salud del paciente». Así, por ejemplo, no será necesario que un paciente consienta por escrito para que se le extraiga una muestra de sangre, de igual modo que no debe consignarse por escrito la autorización para llevar a cabo un procedimiento terapéutico invasivo como es una inyección. El paciente podrá revocar libremente su consentimiento en cualquier momento (art. 8.5 LAP). Cuando éste haya sido consignado por escrito, también la revocación debería constar por escrito.

Por lo que respecta a la información previa al consentimiento para la obtención de la muestra, el art. 4 LAP establece, con carácter general, que 
«los pacientes tienen derecho a conocer, con motivo de cualquier actuación en el ámbito de su salud, toda la información disponible sobre la misma».

La información podrá proporcionarse verbalmente, pero debe dejarse constancia de ello en la historia clínica, y debe comprender, como mínimo, la finalidad y la naturaleza de cada intervención, sus riesgos y sus consecuencias (art. 4 in fine LAP). Ahora bien, cuando el consentimiento deba otorgarse por escrito, la información también debería quedar recogida de igual manera, sin perjuicio de que ésta se ofrezca también oralmente, incluso con datos adicionales a los recogidos en el documento oportuno.

Por supuesto, «la información (...) será verdadera, se comunicará al paciente de forma comprensible y adecuada a sus necesidades y le ayudará a tomar decisiones de acuerdo con su propia y libre voluntad» (art. 4.2 LAP). Será el médico responsable del paciente quien deberá garantiza el cumplimiento del derecho a la información. No obstante, también los profesionales que le atiendan durante el proceso asistencial o le apliquen una técnica o un procedimiento concreto serán responsables de informarle, por ejemplo el sanitario que realiza la extracción de sangre (art. $4.3 \mathrm{LAP}$ ).

$\mathrm{El}$ art. $10 \mathrm{LAP}$ recoge la información básica que hay que proporcionar al paciente antes de recabar su consentimiento escrito ${ }^{8}$. Sería la siguiente: a) las consecuencias relevantes o de importancia que la intervención origina con seguridad; b) los riesgos relacionados con las circunstancias personales o profesionales del paciente; c) los riesgos probables en condiciones normales, conforme a la experiencia y al estado de la ciencia o directamente relacionados con el tipo de intervención; y d) las contraindicaciones.

Por lo que respecta al sujeto a quien debe comunicarse dicha información, de acuerdo con el art. 5.1 LAP, «el titular del derecho a la información es el paciente». No obstante, también podrá informarse a las personas vinculadas a él, por razones familiares o de hecho, en la medida que el paciente lo permita de manera expresa o tácita.

Cuando el paciente, según el criterio del médico que le asiste, carezca de capacidad para entender la información a causa de su estado físico o psíquico, la información se pondrá en conocimiento de las personas vinculadas a él por razones familiares o de hecho (art. 5.3 LAP). No obstante, incluso en tales casos, el paciente deberá ser informado de modo adecuado a sus posibilidades de comprensión, cumpliendo con el deber de informar también a su representante legal (cfr. arts. 5.2 y 9.5 LAP).

Así pues, en el mejor de los escenarios posibles, el sujeto fuente será quien consienta la extracción de la muestra, pero ello no será siempre posible. En ciertas circunstancias será necesario que la información se transmita

${ }^{8}$ Aunque este precepto se refiere a la información previa al consentimiento por escrito, el contenido de la información no debería ser muy diferente cuando se trate del consentimiento verbal. 
a una tercera persona y que sea ésta quien otorgue su consentimiento. Así sucederá en los siguientes casos, contenidos en el art. 9.3 LAP:

a) Cuando el paciente no sea capaz de tomar decisiones, a criterio del médico responsable de la asistencia, o su estado físico o psíquico no le permita hacerse cargo de su situación. Si el paciente carece de representante legal, el consentimiento lo prestarán las personas vinculadas a él por razones familiares o de hecho.

b) Cuando el paciente esté incapacitado legalmente, de acuerdo con lo dispuesto en los arts. 199 y ss. del Código civil. Según este texto legal, «incapaz» es quien no tiene posibilidad de autogobierno, debido a una enfermedad o a una deficiencia. Incapacitar a una persona es privarla de la capacidad de obrar. La incapacitación se produce por decisión judicial motivada en la correspondiente sentencia, la cual determinará su extensión y límites. Esta situación puede modificarse por una nueva sentencia, si cambian las circunstancias.

c) Cuando el paciente menor de edad no sea capaz intelectual ni emocionalmente de comprender el alcance de la intervención. En este caso, el consentimiento lo dará el representante legal del menor después de haber escuchado su opinión si tiene doce años cumplidos. Así pues, interpretando este artículo a sensu contrario, el paciente menor de edad que sea capaz intelectual y emocionalmente de comprender el alcance de la intervención podrá consentir ésta por sí mismo. Además, según este mismo art. 9.3.c) LAP, en el caso de menores «emancipados o con dieciséis años cumplidos, no cabe prestar el consentimiento por representación». Esto es, existe una presunción general de madurez para prestar un consentimiento válido en los menores eman$\operatorname{cipados}^{9} \mathrm{y}$, en todo caso, en los mayores de dieciséis años.

Finalmente, en otros casos y de forma extraordinaria, la obtención de la muestra para su ulterior análisis diagnóstico podría llevarse a cabo incluso sin la autorización del sujeto fuente o de un tercero que lo sustituya. Así sucederá en lo casos previsto en el art. 9.2 LAP: «Los facultativos podrán llevar a cabo las intervenciones clínicas indispensables en favor de la salud del paciente, sin necesidad de contar con su consentimiento, en los siguientes casos: a) Cuando existe riesgo para la salud pública a causa de razones sanitarias establecidas por la Ley. En todo caso, una vez adoptadas las medidas pertinentes, de conformidad con lo establecido en la Ley Orgánica 3/1986,

${ }^{9}$ La emancipación puede producirse, en determinados casos, con catorce años (arts. 48 y 316 del Código civil). Cfr. Sergio Romeo MaLANDA, «El valor jurídico del consentimiento prestado por los menores de edad en el ámbito sanitario», La Ley, 2000-7 p. 1455; Carlos María Romeo CASABONA, «Consentimiento informado y teoría general del Derecho», en Responsabilidad médica y sanitaria, Servicio Central de Publicaciones del Gobierno Vasco, Vitoria-Gasteiz, 2003, p. 83. 
se comunicarán a la autoridad judicial en el plazo máximo de 24 horas siempre que dispongan el internamiento obligatorio de personas; b) Cuando existe riesgo inmediato grave para la integridad física o psíquica del enfermo y no es posible conseguir su autorización, consultando, cuando las circunstancias lo permitan, a sus familiares o a las personas vinculadas de hecho a él».

\subsection{La utilización de materiales biológicos con fines diagnósticos}

Cuando se obtienen materiales biológicos con fines diagnósticos, ya se conocerá el tipo de análisis al que van a ser sometidas, por lo que en ese momento, el sujeto fuente, además de consentir la extracción, también deberá ser informado sobre su uso diagnóstico. Por supuesto, si el diagnóstico desea realizarse sobre una muestra obtenida originariamente con otra finalidad, también deberá informarse de ello al sujeto fuente antes de llevar a cabo dicho análisis, el cual deberá ser consentido por éste.

En principio, será de aplicación la LAP, pues se trata de una actuación con fines diagnósticos en el ámbito de la sanidad ${ }^{10}$. Así pues, las mismas reglas referidas en el apartado anterior respecto a la obtención de la muestras serán igualmente aplicables al análisis clínico practicado sobre ellas. Esto es, el sujeto fuente (o su representante legal) deberá consentir la práctica del análisis clínico una vez que haya sido informado de su finalidad y objetivo.

Sin embargo, la Ley 14/2007, de 3 de julio, de Investigación Biomédica (LIB) regula de forma específica el tema de los diagnósticos genéticos (no así el resto de diagnósticos realizados sobre materiales biológicos, que seguirán rigiéndose por la LAP). Así, el Capítulo II del Título V de la LIB se ocupa de los «análisis genéticos y tratamiento de datos genéticos de carácter personal» ${ }^{11}$. Según el art. $46 \mathrm{LIB}, \ll(\ldots)$ los análisis genéticos se realizarán para la identificación del estado de afectado, de no afectado o de portador de una variante genética que pueda predisponer al desarrollo de una enfermedad específica de un individuo, o condicionar su respuesta a un tratamiento concreto».

Por lo que respecta a la información que debe transmitirse al sujeto fuente antes de que éste emita su consentimiento, el art. 47 establece que «(...) antes de que el sujeto preste el consentimiento (...), deberá recibir la siguiente información por escrito: $1 .^{\circ}$ Finalidad del análisis genético para el cual consiente; $2 .^{\circ}$ Lugar de realización del análisis y destino de la muestra bio-

${ }^{10} \mathrm{Cfr}$. arts 2.2 y 3 LAP.

${ }^{11}$ Por análisis genético se entiende todo «procedimiento destinado a detectar la presencia, ausencia o variantes de uno o varios segmentos de material genético, lo cual incluye las pruebas indirectas para detectar un producto génico o un metabolito específico que sea indicativo ante todo de un cambio genético determinado» [art. 3.a) LIB]. 
lógica al término del mismo, sea aquél la disociación de los datos de identificación de la muestra, su destrucción, u otros destinos, para lo cual se solicitará el consentimiento del sujeto fuente en los términos previstos en esta Ley; $3 .^{\circ}$ Personas que tendrán acceso a los resultados de los análisis cuando aquéllos no vayan a ser sometidos a procedimientos de disociación o de anonimización; 4. ${ }^{\circ}$ Advertencia sobre la posibilidad de descubrimientos inesperados y su posible trascendencia para el sujeto, así como sobre la facultad de éste de tomar una posición en relación con recibir su comunicación; 5. ${ }^{\circ}$ Advertencia de la implicación que puede tener para sus familiares la información que se llegue a obtener y la conveniencia de que él mismo, en su caso, transmita dicha información a aquellos; $6{ }^{\circ}$ Compromiso de suministrar consejo genético, una vez obtenidos y evaluados los resultados del análisis».

El consentimiento deberá ser expreso y específico para la realización de un análisis genético concreto (art. 48.1 LIB). Evidentemente, también «para acceder a un cribado genético será preciso el consentimiento explícito y por escrito del interesado» (art. 48.3 PLIB), si bien en este caso, continúa diciendo este precepto, «el Comité de Ética de la Investigación determinará los supuestos en los que el consentimiento podrá expresarse verbalmente. En todo caso, cuando el cribado incluya enfermedades no tratables o los beneficios sean escasos o inciertos, el consentimiento se obtendrá siempre por escrito».

En relación con sujetos fallecidos, la LIB establece que «[I] (...) se podrán obtener y analizar muestras de personas fallecidas siempre que pueda resultar de interés para la protección de la salud, salvo que el fallecido lo hubiese prohibido expresamente en vida y así se acredite. A tal fin serán consultados los documentos de instrucciones previas y, en su defecto, el criterio de los familiares más próximos del fallecido. [II] El acceso de los familiares biológicos a la información derivada del análisis genético del fallecido se limitará a los datos genéticos pertinentes para la protección de la salud de aquéllos» (art. 48.2 LIB).

Además, «la realización de análisis genéticos diagnósticos sobre preembriones in vivo y sobre embriones y fetos en el útero requerirá el consentimiento escrito de la mujer gestante» (art. 48.4 LIB). Pero este mismo precepto remite a la Ley sobre Técnicas de Reproducción Humana Asistida en lo concerniente a los análisis genéticos de un preembrión in vitro no transferido al útero materno (art. 48.4 in fine LIB). En tales casos será de aplicación el art. 12 Ley 14/2006, de 26 de mayo, sobre técnicas de reproducción humana asistida, relativo al diagnóstico preimplantacional ${ }^{12}$.

${ }^{12}$ Según este precepto: «1. [I] Los centros debidamente autorizados podrán practicar técnicas de diagnóstico preimplantacional para: a) La detección de enfermedades hereditarias graves, de aparición precoz y no susceptibles de tratamiento curativo posnatal con arreglo a los conocimientos científicos actuales, con objeto de llevar a cabo la selección embrionaria de los preembriones no afectos para su transferencia; b) La detección de otras alteraciones 
Por otra parte, el sujeto fuente puede querer recuperar un material biológico obtenido con fines diagnósticos (y que consta en su Historia Clínica) para realizar un segundo diagnóstico en otro centro. Antes de la aprobación de la LIB, los tribunales han emitido sentencias en diversos sentidos. En un caso conocido por la Audiencia Provincial de Vizcaya (Sentencia de 21 de julio de 2003), unos padres de un menor fallecido demandaron al especialista en oncología pediátrica y al especialista en anatomía patológica del hospital de Basurto por, primero, conducta negligente en el diagnóstico y posterior tratamiento erróneo de sarcoma osteogénico de célula pequeña cuando la enfermedad era un sarcoma de Ewing y, segundo, por ocultación de los bloques de parafina y falta de colaboración con la clínica privada que los solicitó para realizar un análisis. Aunque la AP considera que no existió una actuación médica negligente en relación con el diagnóstico y consiguiente tratamiento del paciente menor fallecido, sin embargo, sí estima el motivo referente al anormal funcionamiento del Servicio de Anatomía Patológica, el cual denegó, en un principio, la entrega de la muestra de parafina de la biopsia del tumor cerebral extraída en una intervención quirúrgica y solicitada por los padres para realizar nuevos estudios anatomopatológicos en otro centro, alegando que sólo le quedaban preparaciones únicas (finalmente se comprobó la existencia de bloques de parafina, y se entregó uno a los padres del menor). La estimación de este motivo se fundamenta en la «denegación del derecho de información por la obstrucción en la obtención de la muestra» de parafina de la biopsia del tumor cerebral del hijo. Se condena solidariamente al especialista en anatomía patológica y al Servicio Vasco de Salud a abonar 500.000 pesetas.

Sin embargo, el Tribunal Superior de Justicia de Cantabria (Sentencia de 16 de mayo de 2003) aprueba la decisión de no entregar al paciente las preparaciones histológicas para las biopsias, anulando así la decisión del tribunal de instancia. El juzgado de lo contencioso de Santander había mantenido que del derecho de información clínica del paciente se deriva el derecho a conocer y a estar informado de su historia clínica, y ello abarcaría la entrega de las pruebas histológicas que pueda conservarse en el hospital donde se conservaron. Sin embargo el TSJC opina que el derecho de acceso a la HC

que puedan comprometer la viabilidad del preembrión. [II] La aplicación de las técnicas de diagnóstico preimplantacional en estos casos deberá comunicarse a la autoridad sanitaria correspondiente, que informará de ella a la Comisión Nacional de Reproducción Humana Asistida. 2. La aplicación de técnicas de diagnóstico preimplantacional para cualquiera otra finalidad no comprendida en el apartado anterior, o cuando se pretendan practicar en combinación con la determinación de los antígenos de histocompatibilidad de los preembriones in vitro con fines terapéuticos para terceros, requerirá de la autorización expresa, caso a caso, de la autoridad sanitaria correspondiente, previo informe favorable de la Comisión Nacional de Reproducción Humana Asistida, que deberá evaluar las características clínicas, terapéuticas y sociales de cada caso». 
no fundamenta la solicitud de entrega de las preparaciones histológicas para las biopsias, puesto que son realidades completamente distintas. El derecho de información se refiere, en opinión del TSJC, al informe anatomopatológico que recoge la conclusión diagnóstica del examen de los tejidos.

No cabe duda de que el TSJC tiene razón cuando afirma que el derecho a la información sobre la salud únicamente abarca los datos obtenidos en un proceso asistencial, lo cual se satisface con la entrega del informe del análisis $^{13}$. Ahora bien, puede que el principal error de ambas resoluciones haya sido analizar la cuestión desde la perspectiva del acceso a la información sanitaria y no, como debería haberse hecho, desde la existencia de un posible derecho a la propiedad de la muestra. Como afirma Nicolás Jiménez, de ambas sentencias parece deducirse que los tribunales atribuyen la propiedad del material biológico al centro donde ésta se encuentra almacenada y no al sujeto fuente (éste la habría abandonado y el hospital se habría apropiado de ella $)^{14}$. Si como debiera haberse hecho, los tribunales hubieran partido de la afirmación de condición de propietario de la muestra del sujeto fuente (el ahora reclamante de ésta), no habría existido ningún problema para haber exigido su restitución una vez que ésta fue requerida.

Para evitar estas controversias, alguna Comunidad Autónoma, como es el caso de Castilla-León, ha incluido en su Ley 8/2003, de 8 de abril, sobre derechos y deberes de las personas en relación con la salud, una disposición específica relativa a los «derechos sobre los tejidos o materiales biológicos». Así, el art. 36.1 de la mencionada norma establece lo siguiente: «Las personas a quienes se practique una biopsia o extracción en los centros, servicios o establecimientos sometidos a la presente Ley tienen derecho a disponer de preparaciones de tejidos o materiales biológicos provenientes de aquéllas, con el fin de recabar la opinión de un segundo profesional o para garantizar la continuidad de la asistencia en un centro, servicio o establecimiento diferente». De la misma manera, según el art. 39.2 de Ley de Cantabria 7/2002, de 10 de diciembre, de Ordenación Sanitaria de Cantabria (ley posterior a la sentencia mencionada), «el paciente tiene derecho a disponer de aquellas preparaciones de tejidos o materiales biológicos que provengan de una biopsia o extracción, con la finalidad de recabar la opinión de un segundo profesional o para la continuidad de la asistencia en un centro diferente». De forma muy similar se manifiesta la Ley riojana 2/2002, de 17 de abril, de Salud: «El paciente tiene el derecho a disponer de aquellas preparaciones de tejidos

\footnotetext{
${ }^{13}$ Así también, Pilar NiCOLÁs JiMÉNEZ, «Los derechos del paciente sobre su muestra biológica: distintas opiniones jurisprudenciales», Revista de Derecho y Genoma Humano, n. 19 (2003), p. 224. Como dice esta autora, ello «coincide con el régimen previsto para la historia clínica: el derecho a la información faculta para el acceso a los datos que en ella consten, que se puede satisfacer por una copia, pero no al soporte material».

${ }^{14}$ NiCOLÁs JimÉNEZ, «Los derechos del paciente sobre su muestra biológica: distintas opiniones jurisprudenciales», p. 223.
} 
o materiales biológicos que provengan de una biopsia o extracción, con la finalidad de recabar la opinión de un segundo profesional o para la continuidad de la asistencia en un centro diferente».

La LIB no contiene ninguna disposición análoga a la recogida en la legislación autonómica referida. Únicamente se pronuncia expresamente, manteniendo una postura similar, en relación con los materiales biológicos obtenidas con fines de investigación (art. 58.4 LIB). Según este precepto, «cuando, por razones de salud, el sujeto fuente o su familia lo necesiten podrán hacer uso de las muestras, siempre que estén disponibles y no se encuentren anonimizadas».

En otro orden de cosas, la jurisprudencia ha tenido también la ocasión de pronunciarse sobre los efectos del extravío de material biológico obtenido con fines diagnósticos, lo que impide la realización del correspondiente análisis. Así, la Audiencia Provincial de Madrid, en su Sentencia de 29 de septiembre de 2004 (ponente: Pedro Pozuelo Pérez), ha condenado a una clínica privada a pagar a un paciente dos millones de pesetas (12.000 euros) en concepto de daños morales por la pérdida de una muestra destinada a una biopsia debido a un error humano. La sentencia confirma el fallo del juzgado de primera instancia en el caso de una paciente que se sometió a una operación quirúrgica para la extirpación de un pólipo endometrial. Sin embargo, la muestra no llegó al laboratorio de patología debido, según la declaración del jefe del laboratorio, «a una negligencia o descuido de los empleados de la clínica, que son los encargados de su transporte hasta el laboratorio sin que al mismo llegaron las muestras (sic)». La resolución judicial aclara que el daño moral está representado por el «impacto o sufrimiento psíquico o espiritual que en la persona pueden producir ciertas conductas, actividades o, incluso, resultados, tanto si implican una agresión directa o inmediata a bienes materiales, cual si el ataque afecta al acervo extra-patrimonial o de la personalidad (ofensas a la fama, al honor, honestidad, muerte de una persona allegada, destrucción de objetos muy estimados por el propietario, etc.)» (énfasis añadido). Aplicando estos criterios al caso estudiado, los magistrados consideran que «el extravío de la muestra extirpada a la paciente le ha producido un importante trastorno de orden psicológico; en efecto extraviada la muestra no se han podido hacer las pruebas necesarias a fin de determinar si lo extraído era de componente benigno o maligno, ello lleva directamente una situación de desazón manifestada por la posibilidad de padecer una peligrosa enfermedad sin saberlo; pero es que a mayor abundamiento no habiéndose podido practicar las pruebas de anatomía patológica y sin poder establecerse un diagnostico preciso podría haberse dado la circunstancia, al final no producida que la demandante padeciera una enfermedad de carácter grave y durante un periodo de tiempo no se haya podido tratar de la misma por lo que la existencia de los daños morales evidenciados por ese sufrir psicológico del paciente que se produce aunque cuando no se tenga una personalidad hipocondríaca se han producido». Esta sentencia no se ocupa, sin 
embargo, de una eventual responsabilidad por la perdida del material biológico en sí misma, como bien material propiedad de los demandantes (lo cual plantea, indudablemente, el problema de su valoración económica).

Finalmente, es necesario dejar constancia del Real Decreto 65/2006, de 30 de enero, por el que se establecen requisitos para la importación y exportación de materiales biológicos. Esta norma establece las condiciones para la importación y exportación de muestras de sustancias biológicas destinadas al diagnóstico o investigación en seres humanos (art. 1) ${ }^{15}$, y establece un sistema de registro voluntario que permite su importación y exportación continua.

\subsection{El almacenamiento de materiales biológicos con fines diagnósticos}

Tradicionalmente, los archivos de material biológico se han ido desarrollando con la acumulación de muestras provenientes de procedimientos diagnósticos, y depositadas en los departamentos de patología. Los archivos se componen de materiales obtenidos de intervenciones quirúrgicas, de diversos tipos de biopsias, muestras de fluidos corporales u obtenidas por frotis.

Al finalizarse las investigaciones patológicas, el material biológico es normalmente almacenado como parte del historial médico del paciente. Hay protocolos que establecen periodos mínimos de almacenamiento para las diversas clases de especímenes y, en la práctica, gran parte del material archivado es conservado durante décadas, de tal forma que sea posible una segunda opinión, un seguimiento clínico a largo plazo, incluyendo la comparación con enfermedades posteriores y la posibilidad de volver a analizar el caso clínico de acuerdo con los nuevos avances científicos y los más recientes desarrollos técnicos, con el fin de perfeccionar el diagnóstico inicial. Esta práctica supone, evidentemente, una gran acumulación de material biológico en los hospitales, gran parte del cual podría ser de mucha utilidad en algunas investigaciones biomédicas.

El Comité de Bioética de Cataluña ha señalado que «en el caso de biopsias y autopsias se necesita el CI para hacerlas. Los servicios de anatomía patológica tienen la obligación de conservar el material para posteriores revisiones o pruebas adicionales en beneficio del enfermo. Por lo tanto, no se necesita un CI específico de almacenaje: es imperativo hacerlo así. Para una utilización posterior es conveniente que los documentos de CI que se utili-

${ }^{15}$ Esta norma se refiere a la «importación y exportación», lo cual plantea la duda de si su ámbito de aplicación se extiende a las muestras que provienen de un Estado Miembro de la Unión Europea. A este respecto, hay que tener presente que la entrada en territorio español de cualquier bien proveniente de un Estado Miembro, no es stricto sensu una «importación», término que, jurídicamente, tiene un sentido fiscal, esto es, se trata de la circulación de mercancías sujeta a un régimen aduanero y tributario. Así pues, desde la implantación del mercado único, entre los Estados Miembros no se producen importaciones de mercancías, sino «adquisiciones intracomunitarias de bienes». 
zan para intervenciones quirúrgicas incluyan un apartado donde se prevea la aprobación del paciente para que el tejido sobrante del que se haya utilizado para el diagnóstico histopatológico correcto se pueda utilizar para investigación o docencia» ${ }^{16}$.

Igualmente, a lo largo de los años también se han estado acumulando fichas que contenían manchas de sangre provenientes de niños recién nacidos (normalmente conocidas como fichas Guthrie). Las muestras se obtienen a los tres días del nacimiento y se analiza la sangre para detectar un cierto número de enfermedades tratables, tras lo cual se han almacenado por tiempo indefinido y con la identificación del sujeto fuente.

El almacenamiento de materiales biológicos con fines diagnósticos no está regulado actualmente en ningún texto normativo. La LIB regula por vez primera en nuestro ordenamiento jurídico los «biobancos», entendiéndose como tales todo «establecimiento público o privado, sin ánimo de lucro, que acoge una colección de materiales biológicos concebida con fines diagnósticos o de investigación biomédica y organizada como una unidad técnica con criterios de calidad, orden y destino» (art. 3 d). Posteriormente, el Capítulo IV del Título V de la Ley se ocupa más detenidamente de los biobancos, tratando, entro otras cuestiones, los requisitos exigidos para su constitución, su organización, el registro de biobancos, o los derechos del sujeto fuente respecto a la obtención y utilización de las muestras que van a componer dicho establecimiento.

Esta definición aparentemente comprende los biobancos con fines exclusivamente diagnósticos. Por lo tanto, las reglas contenidas en la Ley deberían ser de aplicación a éstos. Sin embargo, de la lectura de la LIB resulta evidente que el legislador, cuando elaboró esta norma (especialmente el Capítulo dedicado a los biobancos), lo que tenía en mente eran aquellas colecciones constituidas con fines de investigación biomédica que sirvan de depósito organizado de muestras de muy diversa tipología representativas de la población de referencia, que puedan ser utilizadas en un futuro en proyectos de investigación de interés científico aún no concreta-

\footnotetext{
${ }^{16}$ Comité de BioÉtica de CATAluña, Problemas éticos en el almacenamiento y la utilización de materiales biológicos, Barcelona, 2004, p. 78

${ }^{17}$ Para el Grupo PARA El Uso DE MATERIALES BIOLÓGicos PARA INVESTIGACIÓN BiOMÉDICA, Guía práctica para la utilización de materiales biológicos en investigación biomédica, Instituto Roche, Madrid, 2006, pp. 15 y s., «lo que diferencia a un biobanco de una colección "inerte" es que el primero intercambia con otras instituciones científicas el material que posee, que debe aumentar y mejorar constantemente, y el segundo se limita a ser un reservorio de muestras» (cfr. también, Anne CAmbon-Thomsen/Pascal Ducournau/PierreAntoine GourRaud/David PonTILLE, «Biobanks for genomics and genomics for biobanks», Comparative and Functional Genomics, n. ${ }^{\circ} 4$ [2003], p. 629). Como decía, ésta es también la idea que tiene el legislador en mente cuando ha redactado el Capítulo IV del Título V de la LIB. Sin embargo, ello no se corresponde con la definición de biobanco que el propio legislador ofrece en dicha Ley.
} 
$\operatorname{dos}^{17}$. Esto puede generar algunas dudas sobre la aplicabilidad de todas las disposiciones contenidas en la LIB a todo tipo de biobancos, tanto los creados con fines de investigación, como aquellos constituidos con una finalidad diagnóstica, especialmente si tenemos en cuenta que la LIB prevé remisiones al capítulo relativo al tratamiento de materiales biológicos con fines de investigación biomédica a fin de completar su contenido. Y tales disposiciones no son aplicables al tratamiento de materiales biológicos con fines diagnósticos.

Las reglas de constitución, inspección y clausura contenidas en los arts. 63, 64 y 71 LIB únicamente son aplicables a algunos biobancos, entre los que no se encuentran los biobancos con fines diagnósticos, sin perjuicio de que la Administración Pública pueda establecer también en estos casos las oportunas medidas de inspección y control. Lo mismo cabe decir en relación con el art. 66 LIB, relativo a la organización del biobanco. No parece viable que cada vez que un centro hospitalario requiera almacenar materiales biológicos durante un procedimiento asistencial tenga, por ejemplo, que nombrar un director científico y constituir dos comités externos, uno científico y otro de ética ${ }^{18}$.

Además, según dispone el art. 67.4 LIB, «no estarán sometidas a la indicada inscripción [en el Registro Nacional de Biobancos para Investigación Biomédica] las colecciones mantenidas por personas físicas para usos exclusivamente personales, ni las muestras, aunque estén ordenadas como colección, que se hayan obtenido para la realización de los análisis pertinentes con fines diagnósticos y, en su caso, de tratamiento del sujeto fuente, y que no se mantengan almacenados durante un período de tiempo superior al

Evidentemente, los biobancos no son colecciones «inertes» ya que éstos deben cumplir ciertos criterios de destino, esto es, son colecciones que sirven a un fin preestablecido, pero ese destino es más variado que el mero intercambio de muestras para investigación biomédica, tal y como correctamente apunta el COMITÉ DE ÉTICA DEL INSTITUTO DE INVESTIGACIÓN DE ENFERMEDADES RARAS, «Recomendaciones sobre los aspectos éticos de las colecciones de muestras y bancos de materiales humanos con fines de investigación biomédica», Revista Española de Salud Pública, n. 2 (2007), p. 97.

A este mismo respecto, Bernice S. ElgER/Arthur L. CAPLAN, «Consent and anonymization in research involving biobanks», EMBO Reports, n. ${ }^{\circ} 7$ (2006), p. 661, señalan que si bien el término «biobanco» actualmente sirve para describir una variada tipología de archivos de materiales biológicos, sin embargo originariamente se refería a grandes bancos poblacionales de materiales biológicos con información asociada a ellos. Sobre la amplitud de significados del término biobanco, vid. Jane KAYE, «Do we need a uniform regulatory system for biobanks across Europe?», European Journal of Human Genetics, n. ${ }^{\circ} 14$ (2006), pp. 245 y s.; Don Chalmers, «Ethical Principles for Research Governance of Biobanks», Journal of International Biotechnology Law, n. 3 (2006), p. 222.

${ }^{18} \mathrm{Vid}$. en este mismo sentido, German National Ethics Council, Biobanks for Rese$\operatorname{arch}, 2004$, pp. 63 y s. 
cumplimiento de estos objetivos» (énfasis añadido) ${ }^{19}$. No queda claro en la Ley si estos «biobancos» deben ser inscritos en la Agencia Española de Protección de Datos. Sin embargo, parece que ello será necesario siempre que éstos contengan bases de datos asociadas a muestras relativas a personas identificadas o identificables.

El Comité de Bioética de Cataluña explica como «(...) los servicios de anatomía patológica tienen la obligación de conservar el material para posteriores revisiones o pruebas adicionales en beneficio del enfermo. Por lo tanto, no se necesita un CI específico de almacenaje: es imperativo hacerlo así. Para una utilización posterior es conveniente que los documentos de CI que se utilizan para intervenciones quirúrgicas incluyan un apartado donde se prevea la aprobación del paciente para que el tejido sobrante del que se haya utilizado para el diagnóstico histopatológico correcto se pueda utilizar para investigación o docencia» ${ }^{20}$. Para un sector de la doctrina, ello es debido a la conveniencia de aplicar el régimen de la historia clínica a los materiales biológicos almacenados ${ }^{21}$. De acuerdo con esta postura, los servicios de anatomía patológica tendrían la obligación de conservar las muestras obtenidas en el proceso diagnóstico, del mismo modo que existe la obligación de mantener los datos de la historia clínica. Y ante esta obligación legal no cabe derecho de oposición por parte del paciente ${ }^{22}$. Es decir, las muestras se almacenarán por el periodo mínimo fijado en la legislación aplicable (estatal y autonómica) para la conservación de la documentación clínica. Así pues, el almacenamiento de materiales biológicos obtenidos con fines diagnósticos en biobancos se producirá incluso si el sujeto fuente no es consciente de ello y no ha prestado su consentimiento. Sin embargo, cuando el análisis al que van a ser sometidas las muestras tengan un carácter genéti-

${ }^{19}$ Por lo tanto, si existe la intención de almacenar los materiales biológicos obtenidos originariamente con fines diagnósticos por largos periodos de tiempo (pues se considera que dichas muestras pueden ser de gran utilidad en un futuro para el desarrollo de ciertos proyectos de investigación), entonces habrá que aplicar todas las reglas de la LIB relativas a los biobancos con fines de investigación biomédica, incluida la inscripción en el Registro Nacional de Biobancos para Investigación Biomédica.

${ }^{20}$ Comité de BioÉtica de CATAluña, Problemas éticos en el almacenamiento y la utilización de materiales biológicos, Barcelona, 2004, p. 78. En el mismo sentido, Francesc ABEL/Victoria Cusí, «Bancos de información genética. Problemas éticos y jurídicos» en Xavier Abel Lluch (dir.), El juez civil ante la investigación biomédica, Cuadernos de Derecho Judicial, Vol. X, Consejo General del Poder Judicial, Madrid, 2004, pp. 445 y 461.

${ }^{21}$ Pilar NiCOLÁs JimÉNEZ, La protección jurídica de los datos genéticos de carácter personal, Cátedra Interuniversitaria de Derecho y Genoma Humano-Comares, Bilbao-Granada, 2006, pp. 348 y 364.

${ }^{22}$ Cfr. arts. 15 LAP y 6.4 de la Ley Orgánica 15/1999, de 13 de diciembre, de Protección de Datos de Carácter Personal. Vid. asimismo, Nicolás JimÉnEZ, La protección jurídica de los datos genéticos de carácter personal, pp. 192 y ss. 
$\mathrm{co}^{23}$, la LIB sí que prevé una regla específica al respecto. Así, el art. 47 LIB establece que « $(\ldots)$ antes de que el sujeto preste el consentimiento [para la realización de un análisis genético] (...), deberá recibir la siguiente información por escrito: (...) 2. ${ }^{\circ}$ Lugar de realización del análisis y destino de la muestra biológica al término del mismo, sea aquél la disociación de los datos de identificación de la muestra, su destrucción, u otros destinos, para lo cual se solicitará el consentimiento del sujeto fuente en los términos previstos en esta Ley (...)» (énfasis añadido).

De esta forma, se ofrece al sujeto fuente la posibilidad de ejercer un mayor control sobre su material biológico, a la vez que se permite conseguir un valor añadido en relación con el material biológico si se acuerda destinar el material excedente a un biobanco con fines de investigación biomédica; debe cumplirse, en tal circunstancia, las reglas establecidas en la LIB más arriba expuestas. Si en este momento no se prevé este uso secundario para investigación biomédica de las muestras obtenidas, entonces cualquier uso posterior del material biológico con dicho fin requerirá la obtención del consentimiento del sujeto fuente, tal y como prevé el art. 58.2 LIB.

En sentido similar al anterior, respecto a los materiales biológicos obtenidos y almacenados con fines diagnósticos, del art. 67.4 LIB se desprende que éstos no podrán conservarse durante un periodo de tiempo superior al necesario para el cumplimiento de sus objetivos. Si se desea mantener almacenados los materiales biológicos con otros fines (normalmente de investigación) una vez que éstos hayan cumplido su finalidad originaria, entonces habrá que solicitar el consentimiento del sujeto fuente ${ }^{24}$. Lo anterior viene a confirmar algo que la doctrina venía ya defendiendo, esto es, que los materiales biológicos, siempre que correspondan a personas identificadas o identificables, no podrán ser almacenados de forma rutinaria (y menos aún por tiempo indefinido) tras extracciones quirúrgicas o análisis de sangre, sin una finalidad o necesidad concreta ${ }^{25}$.

Por lo que respecta al tiempo requerido para el cumplimiento de los objetivos, y de acuerdo con lo expuesto más arriba, podría tomarse como referencia la legislación relativa a la historia clínica (salvo que exista una norma expresa relativa al almacenamiento de materiales biológicos con fines diagnósticos). El art. 17.1 LAP establece que «los centros sanitarios tienen la obligación de conservar la documentación clínica en condiciones que

${ }^{23}$ Según el art. 46 LIB, «(...) los análisis genéticos se realizarán para la identificación del estado de afectado, de no afectado o de portador de una variante genética que pueda predisponer al desarrollo de una enfermedad específica de un individuo, o condicionar su respuesta a un tratamiento concreto».

${ }^{24}$ Cfr. Australian Law Reform Commission, Essentially Yours: The Protection of Human Genetic Information in Australia, Vol. I, 2003, pp. 513 y s.

${ }^{25}$ Vid. NiCOLÁs JiMÉNEZ, La protección jurídica de los datos genéticos de carácter personal, pp. 348 y 364. 
garanticen su correcto mantenimiento y seguridad, aunque no necesariamente en el soporte original, para la debida asistencia al paciente durante el tiempo adecuado a cada caso y, como mínimo, cinco años contados desde la fecha del alta de cada proceso asistencial». Sin embargo, algunas normas autonómicas existentes en este ámbito establecen periodos mínimos más amplios $^{26}$. En definitiva, en tanto pueda ser útil para la salud del paciente o de terceros, el almacenamiento de la muestra está justificado, si bien no es obligatorio más allá de los periodos mínimos establecidos.

\section{EL TRATAMIENTO DE MATERIALES BIOLÓGICOS CON FINES TERAPÉUTICOS}

\subsection{La relevancia de los materiales biológicos con fines terapéuticos}

Los materiales biológicos pueden obtenerse con fines terapéuticos con un doble propósito:

Por un lado, pueden ser necesarias intervenciones quirúrgicas con la finalidad directa de tratar una determinada afección. Tales intervenciones pueden llevar aparejada la retirada de cierta cantidad de tejidos, porciones de órganos o, incluso, órganos completos con una funcionalidad muy reducida o nula. Una vez obtenidos, su destino puede ser muy variado: diagnóstico (análisis histológicos), investigación, fines educativos, etc. También es posible su destrucción (normalmente, incineración). Una técnica usual es preservarlos en una solución fijadora especial, empleando cera de parafina, dando lugar a un bloque de cera, con todas las propiedades biológicas del tejido, de tal forma que pueden obtenerse láminas muy finas de dicho elemento y llevar a cabo los análisis pertinentes. Estas muestras pueden almacenarse en los hospitales durante largos periodos de tiempo, y ser utilizadas con fines muy variados, incluidos nuevos análisis diagnósticos según vayan desarrollándose nuevas formas de terapia. Otra técnica de almacenamiento de estas muestras es la congelación, lo cual también permite su mantenimiento durante largos periodos de tiempo.

Por otro lado, también es posible la obtención de materiales biológicos sanos para utilizar con fines terapéuticos en el propio sujeto del cual han sido obtenidas (autotrasplante) o en terceros (heterotrasplante). Lo más común es la donación de cierto tipo de materiales para su posible uso terapéutico por terceras personas: si la donación se hace en vida del donante/sujeto fuente, generalmente se tratará de sangre, médula ósea u otros tejidos, o incluso algunos órganos (como el riñón), o parte de ellos

${ }^{26}$ Andrés Domínguez Luelmo, Derecho sanitario y responsabilidad médica, Editorial Lex Nova, Valladolid, 2003, pp. 474 y ss. 
(como sucede con el hígado). La transfusión de sangre es probablemente el uso de material biológico más familiar para el público, y la donación de sangre para su incorporación a bancos de sangre está establecida desde hace largo tiempo. La sangre está formada por tres elementos, principalmente: plasma, plaquetas y células rojas. El uso más normal es el de la utilización de células rojas con plasma para reemplazar la sangre que se ha perdido (transfusión). Pero, además, el plasma en sí mismo tiene gran valor en varios procedimientos terapéuticos (por su riqueza de proteínas, anticuerpos y otros factores biológicos), tales como el tratamiento de la hemofilia o la prevención de enfermedades infecciosas. Su utilización también ha hecho posible las operaciones cardiacas y vasculares. Si la donación se produce post-mortem, ésta podrá comprender también el resto de órganos.

Por su parte, el trasplante de médula ósea se utiliza fundamentalmente para tratar la leucemia y ciertas dolencias hereditarias. La médula ósea es una sustancia que se encuentra en los huesos huecos de la cadera, piernas y brazos. Células troncales hematopoyéticas, que se encuentran en la médula ósea, producen toda la sangre del sistema circulatorio, incluyendo las células rojas, que transportan el oxígeno; las células blancas, que dan origen al sistema inmonológico del cuerpo; y las plaquetas, que permiten la coagulación sanguínea. Los donantes deben ser estrictamente seleccionados para asegurar la compatibilidad.

Pero como decíamos, también pueden obtenerse materiales biológicos para su uso terapéutico en el propio sujeto del cual proceden (por ejemplo, autotrasplantes de piel o de grasa). E incluso la obtención de la muestra puede hacerse con la finalidad de su almacenamiento para posibles usos terapéuticos futuros, tanto del sujeto fuente como de terceros. Para ello, se pueden utilizar células provenientes del cordón umbilical, cuyo almacenamiento está aumentando en tiempos recientes. La sangre del cordón umbilical es muy rica en células troncales y se utiliza para tratar un importante número de desórdenes sanguíneos, especialmente en niños.

\subsection{La obtención de materiales biológicos con fines terapéuticos}

Las reglas son diferentes si se trata de fines terapéuticos para el propio donante, por ejemplo autotrasplante de alguún tejido, o si se trata de obtención de materiales biológicos para cesión a un tercero.

\subsubsection{Fines terapéuticos para el sujeto fuente}

Cuando el material biológico se obtiene en el curso de un procedimiento terapéutico para el propio sujeto fuente, serán de aplicación las mismas reglas a las que nos referíamos más arriba en relación con los fines diagnósticos. Habrá que atenerse, pues, a lo establecido en la LAP. Esto sirve tanto 
cuando el material obtenido tiene una finalidad terapéutica directa y se va a reutilizar en el propio paciente (por ejemplo, transplante de piel en el caso de quemados), como cuando la terapia precisamente consiste en la extirpación del material biológico en cuestión.

Estas mismas reglas se aplicarán cuando no se trate de un procedimiento terapéutico en sentido estricto, pero sí nos encontremos, sin embargo, ante una intervención médico-quirúrgica en sentido amplio y que tenga como finalidad, o al menos de ella se derive, la obtención de material biológico del paciente. Así sucede, por ejemplo, en los casos de ciugía estética (por ejemplo, en una liposucción).

Además de dicha Ley, en ciertas intervenciones deberá tenerse en cuenta, adicionalmente, lo establecido en la normativa específica. Por ejemplo, en los casos de donaciones autólogas y las autotransfusiones de sangre habrá que acudir también al Capítulo V del Real Decreto 1088/2005, de 16 de septiembre, por el que se establecen los requisitos técnicos y condiciones mínimas de la hemodonación y de los centros y servicios de transfusión.

Por donación autóloga se entiende la sangre y componentes sanguíneos extraídos de una persona y dedicados exclusivamente a su transfusión posterior u otra aplicación terapéutica a la misma persona. Por su parte, se entiende por autotransfusión la transfusión en la que el donante y receptor son la misma persona y en la que se emplea sangre y componentes sanguíneos depositados previamente (art. 21.1 y 2 Real Decreto 1088/2005). La autotransfusión sólo podrá realizarse por prescripción médica (art. 21.3 Real Decreto 1088/2005).

Antes de autorizar la extracción de sangre, el donante deberá ser informado de una serie de cuestiones contenidas en la referida normativa, en concreto en su anexo I.A. ${ }^{27}$ Como mínimo, se le facilitará información: a) sobre la posibilidad de exclusión y las razones por las que el procedimiento no se llevará a cabo si existe riesgo para su salud tanto como donante como receptor (apartado 2); b) sobre la naturaleza de los procedimientos que se siguen en el proceso de donación, y sobre los riesgos asociados, en concreto, la posibilidad de que la sangre autóloga o sus componentes no resulten suficientes para las necesidades previstas (apartado 5); c) sobre la posibilidad que tiene el donante de realizar las preguntas que considere oportunas (apartado 10). Además, de acuerdo con el art. 23 Real Decreto 1088/2005 y el Anexo II apartados C.1 y C.2, existen ciertos criterios de exclusión para donaciones autólogas y autotransfusiones, tales como la enfermedad cardiaca grave, o la existencia, en ciertos casos, de antecedentes de hepatitis B, entre otros.

${ }^{27}$ Cfr. art. 22 Real Decreto 1088/2005. 
Los componentes autólogos que no hayan sido trasfundidos no deberán utilizarse para transfusión homóloga ni para fraccionamiento ${ }^{28}$ (art. 27 Real Decreto 1088/2005). De acuerdo con esto, la sangre obtenida para autotransfusión no podrá destinarse a heterotransfusión.

Por su parte, en relación con las células y tejidos humanos, el Real Decreto 1301/2006, de 10 de noviembre, por el que se establecen las normas de calidad y seguridad para la donación, la obtención, la evaluación, el procesamiento, la preservación, el almacenamiento y la distribución de células y tejidos humanos y se aprueban las normas de coordinación y funcionamiento para su uso en humanos, expresamente excluye de su ámbito de aplicación «las células y tejidos utilizados como injertos autólogos dentro del mismo proceso quirúrgico» ${ }^{29}$ (art. 1.3.a). En tales casos, será de aplicación lo establecido en la LAP. Sin embargo, esta norma sí que es de aplicación a los casos de obtención de células y tejidos de una persona viva para su procesamiento y posterior uso autólogo ${ }^{30}$. Además, como veremos posteriormente, también prevé la posibilidad de que existan establecimientos entre cuyas actividades figure la preservación de células y/o tejidos para un eventual uso autólogo ${ }^{31}$.

\subsubsection{Fines terapéuticos para terceros}

Cuando la obtención del material biológico se realiza con fines de donación para el tratamiento de otros (donación homóloga), los requisitos deberán ser más estrictos, ya que no existe un beneficio terapéutico para el donante.

Siempre que se requiera un acto médico, será de aplicación la LAP, pero además pueden existir otras normas que establezcan algunos requisitos específicos, como de hecho sucede en los casos de donación de órganos, tejidos y sangre.

${ }^{28} \mathrm{El}$ fraccionamiento de la sangre permite administrar de forma adecuada a cada paciente el componente de la sangre que realmente le hace falta. Así, se pueden realizar transfusiones de hematíes (glóbulos rojos), transfusiones de plaquetas, transfusiones de plasma o componentes del plasma, etc.

${ }^{29} \mathrm{El}$ art. 2.2.b) de este Real Decreto define uso autólogo como el «proceso mediante el cual las células o los tejidos son extraídos y aplicados a la misma persona».

${ }^{30}$ Vid. art. 7.2 Real Decreto 1301/2006.

${ }^{31}$ De acuerdo con el art. 2.2.b) del Real Decreto, por uso autólogo eventual debe entenderse la obtención de células y/o tejidos «con la finalidad de ser preservados para su aplicación hipotética futura en la misma persona, sin que exista una indicación médica establecida en el momento de la obtención e inicio de la preservación». 


\subsubsection{LA DONACIÓN DE ÓRGANOS}

La regulación relativa a la obtención de órganos con fines terapéuticos para terceros, esto es, para heterotrasplante, está recogida fundamentalmente en los siguientes textos normativos: Ley 30/1979, de 27 de octubre, sobre extracción y trasplante de órganos, y Real Decreto 2070/1999, de 30 de diciembre, por el que se regulan las actividades de obtención y utilización clínica de órganos humanos

La extracción de órganos u otras piezas anatómicas de fallecidos podrá hacerse previa comprobación de la muerte siempre que éstos no hubieran dejado constancia expresa de su oposición (arts. 5.1 y 2 Ley 30/1979, y 10.2 y Anexo I Real Decreto 2070/1999) ${ }^{32,33}$. En el mismo sentido, el art. 10.1 Real Decreto 2070/1999 señala que la obtención de órganos de donantes fallecidos para fines terapéuticos podrá realizarse si la persona fallecida, de la que se pretende extraer órganos, no ha dejado constancia expresa de su oposición a que después de su muerte se realice la extracción de órganos. Dicha oposición, así como su conformidad si la desea expresar, podrá referirse a todo tipo de órganos o solamente a alguno de ellos, y será respetada cualquiera que sea la forma en la que se haya expresado. En el caso de que se trate de menores de edad o personas incapacitadas, la oposición podrá hacerse constar por quienes hubieran tenido en vida de aquéllos su representación legal, conforme a lo establecido en la legislación civil.

Según este mismo art. 10.1 Real Decreto 2070/1999, siempre que se pretenda proceder a la extracción de órganos de donantes fallecidos, la persona a quien corresponda dar la conformidad para la extracción o en quien delegue deberá realizar las siguientes comprobaciones pertinentes: 1. información sobre si el interesado hizo patente su voluntad a alguno de sus fami-

32 «Cuando dicha comprobación se base en la existencia de datos de irreversibilidad de las lesiones cerebrales y, por tanto, incompatibles con la vida, el certificado de defunción será suscrito por tres médicos, entre los que deberán figurar un neurólogo o neurocirujano y el jefe del servicio de la unidad médica correspondiente, o su sustituto; ninguno de estos facultativos podrá formar parte del equipo que vaya a proceder a la obtención del órgano a efectuar el trasplante» (art. 5.1 Ley 30/1979). En el mismo sentido, según el 10.2 Real Decreto 2070/1999, «los citados profesionales deberán ser médicos con cualificación o especialización adecuadas para esta finalidad, distintos de aquellos médicos que hayan de intervenir en la extracción o el trasplante y no estarán sujetos a las instrucciones de éstos. La muerte del individuo podrá certificarse tras la confirmación del cese irreversible de las funciones cardiorrespiratorias o del cese irreversible de las funciones encefálicas. Será registrada como hora de fallecimiento del paciente la hora en que se completó el diagnóstico de la muerte».

${ }^{33}$ Según la Disposición Adicional Segunda Ley 30/1979, «(...) las extracciones anatómicas efectuadas para la práctica de transplantes de córnea y de otros tejidos que reglamentariamente se determinen podrán ser realizadas sin demora y en los propios lugares del fallecimiento». 
liares o de los profesionales que le han atendido en el centro sanitario, a través de las anotaciones que éstos hayan podido realizar en el Libro de Registro de Declaraciones de Voluntad o en la historia clínica; y 2. examen de la documentación y pertenencias personales que el difunto llevaba consigo. Además, siempre que las circunstancias no lo impidan, se deberá facilitar a los familiares presentes en el centro sanitario información sobre la necesidad, naturaleza y circunstancias de la extracción, restauración, conservación o prácticas de sanidad mortuoria.

No obstante lo anterior, esto es, aunque la legislación española claramente ha optado por un modelo de consentimiento presunto, de tal manera que se presume que el sujeto fallecido consiente la donación salvo que expresa o tácitamente haya manifestado lo contrario, en la práctica se procede a solicitar el consentimiento expreso y escrito de la familia del donante ${ }^{34}$.

Las personas presumiblemente sanas que falleciesen en accidente o como consecuencia ulterior de éste se considerarán, asimismo, como donantes, si no consta oposición expresa del fallecido. A tales efectos debe constar la autorización del juez al que corresponda el conocimiento de la causa, el cual deberá concederla en aquellos casos en que la obtención de los órganos no obstaculizare la instrucción del sumario por aparecer debidamente justificadas las causas de la muerte (art. 5.3 Ley 30/1979) ${ }^{35}$.

Sin embargo, la insuficiencia de órganos provenientes de personas fallecidas ha puesto de manifiesto la necesidad de utilizar órganos procedentes de personas vivas, lo cual se ha hecho factible gracias, en gran medida, a la notable mejora de los inmunosupresores. Su modalidad más sencilla y frecuente es el transplante de riñón, pero también es común el trasplante de hígado. En el futuro esta posibilidad puede extenderse al pulmón y al páncreas. Pero el trasplante inter vivos plantea dilemas éticos y jurídicos diferentes a los trasplantes de fallecidos.

La obtención de un órgano (sano) procedente de un sujeto vivo supone una disminución de su integridad corporal, lo cual, trasladado al ámbito jurídico-penal supondría la comisión de un delito de lesiones ${ }^{36}$, contenidos en

${ }^{34}$ Vid. más ampliamente al respecto, Asier UrRuEla MorA, «Trasplante de órganos y tejidos: aspectos jurídicos y sociológicos ligados al consentimiento familiar», en Carlos María Romeo Casabona (coord.), El nuevo régimen jurídico de los trasplantes de órganos y tejidos, Comares, Granada, 2005, pp. 335 y ss.

${ }^{35}$ En el mismo sentido, el art. 10. 5 Real Decreto 2070/1999, señala que «en los casos de muerte accidental, así como cuando medie una investigación judicial, antes de efectuarse la extracción de órganos deberá recabarse la autorización del juez que corresponda, el cual, previo informe del médico forense, deberá concederla siempre que no se obstaculice el resultado de la instrucción de las diligencias penales».

${ }^{36}$ Vid. a este respecto, Carlos María ROMEO CASABONA, «Los principios jurídicos aplicables a los trasplantes de órganos y tejidos», en Carlos María RoMEO CASABONA (coord.), El nuevo régimen jurídico de los trasplantes de órganos y tejidos, Comares, Granada, 2005, pp. 16 y ss. 
los arts. 147 y ss. del Código penal español de 1995 (CP), aunque se cuente con el consentimiento del donante, pues de acuerdo con el art. $155 \mathrm{CP}$, «en los delitos de lesiones, si ha mediado el consentimiento válida, libre, espontánea y expresamente emitido del ofendido, se impondrá la pena inferior en uno o dos grados». Es decir, la pena únicamente se vería atenuada. Para eliminar este obstáculo, el art. $156 \mathrm{CP}$ establece una regla especial, aplicable al caso que nos ocupa. Así, según este precepto, «no obstante lo dispuesto en el artículo anterior, el consentimiento válida, libre, consciente y expresamente emitido exime de responsabilidad penal en los supuestos de trasplante de órganos efectuado con arreglo a lo dispuesto en la Ley (...)».

De acuerdo con esta regulación, esencialmente los arts. 4 Ley 30/1979 y 9 Real Decreto 2070/1999, la obtención de órganos procedentes de un donante vivo, para su ulterior injerto o implantación en otra persona, sólo podrá realizarse si el donante es mayor de edad y goza de plenas facultades mentales, una vez que éste ha sido previamente informado de las consecuencias de su decisión. De esta forma, no podrá obtenerse ningún tipo de órgano de personas que, por deficiencias psíquicas o enfermedad mental o por cualquiera otra causa, no puedan otorgar su consentimiento expreso, libre y consciente. Tampoco podrá realizarse la extracción de órganos a menores de edad, aunque se cuente con su consentimiento o el de su representante legal ${ }^{37}$. Para Romeo CASABONa, «si bien es cierto que con este criterio se impide atender casos vitales para el receptor, la experiencia conocida en algunos países, de claro abuso del menor por parte de sus padres, aunque actúen movidos por el deseo de salvar la vida de otro hijo, aconseja mantener una protección especial de estas personas» ${ }^{38}$. Ahora bien, en la práctica judicial se ha admitido en algún caso excepcional, por medio de un expediente de jurisdicción voluntaria, que un menor de edad con suficiente capacidad de juicio pueda ser donante de un órgano regenerable (parte del hígado), si se trata de la única opción posible para salvar la vida de una tercera persona con la que tenga una estrecha relación (por ejemplo, un hijo) ${ }^{39}$, decisión que, independientemente de su bondad, resulta muy dudosa desde un punto de vista de estricta legalidad.

La información deberá hacer referencia a las consecuencias previsibles de orden somático, psíquico y psicológico, a las eventuales repercusiones que la donación pueda tener sobre su vida personal, familiar y profesional, así como a los beneficios que con el transplante se espera que haya de conseguir el receptor. En ningún caso se extraerán ni se utilizarán órganos de

${ }^{37}$ Cfr. art. 9.3 Ley 41/2002.

${ }^{38}$ Romeo Casabona, «Los principios jurídicos aplicables a los trasplantes de órganos y tejidos», p. 23.

${ }^{39}$ Diario El Mundo, 23 de octubre de 2007. 
donantes vivos cuando por cualquier circunstancia pudiera considerarse que media condicionamiento económico o de otro tipo, social o psicológico.

El consentimiento para extraer un órgano de un donante vivo es un «acto complejo sucesivo y continuo ${ }^{40}$. Por un lado, se requiere que la persona muestre su voluntad de ser donante en dos momentos diferentes: a) se necesita un primer consentimiento para ser evaluado como potencial donante (capacidad y requisitos médicos), esta fase puede dilatarse en el tiempo durante semanas; y b) se exige un segundo consentimiento, dirigido ya en particular a la extracción del órgano, una vez superados los exámenes médicos y pruebas complementarias, y de ser considerado como donante idóneo. Por otro lado, se exige una ratificación (expresa o tácita) en el momento inmediatamente previo a la intervención.

El estado de salud física y mental del donante deberá ser acreditado por un médico distinto del o de los que vayan a efectuar la extracción y el trasplante. Se garantiza, de esta forma, la transparencia del proceso y puede valorarse objetivamente la libertad o no del donante para consentir la donación.

Es precisamente la cuestión de la libertad uno de los puntos más importantes y, a la vez, más difíciles de valorar. Así, a la hora de prestar el consentimiento por parte del donante vivo habrá que asegurarse de que éste no está viciado debido a la presión del entorno que se suele producir en tales casos. Igualmente, en el marco de la donación de órganos de vivo (ámbito en el que normalmente existe una relación familiar o genética entre donante y receptor) la libertad no suele ser absoluta, al menos en la esfera psicológica o emocional, pues el sufrimiento del ser querido estará condicionando fuertemente en el plano interno la decisión a adoptar. Y es que una persona puede sentirse libre aun existiendo una coacción moral que vicia su consentimiento, cuando alguien se siente culpable si no hace lo que los demás esperan de él.

En cualquier caso, este supuesto condicionamiento interno no puede viciar por sí mismo el consentimiento del donante. Para que se pueda afirmar que el consentimiento no es libre, habrá que acreditar la existencia de un vicio real que elimine la voluntad del sujeto (presión externa, amenaza, información insuficiente o manipulada, precio, etc.).

El potencial donante, tras expresar su voluntad de donar un órgano en vida, será sometido a unos exhaustivos exámenes médicos, para comprobar su idoneidad como posible donante. Igualmente, éste será informado de forma rigurosa sobre distintas cuestiones relativas al trasplante. Así, por ejemplo, el donante será previamente informado, como mínimo, de a) los riesgos

${ }^{40}$ Víctor ANGoitia Gorostiaga, «El régimen reglamentario de la extracción y trasplante de órganos», en Carlos María Romeo CASABOna (coord.), El nuevo régimen jurídico de los trasplantes de órganos y tejidos, Comares, Granada, 2005, p. 198. 
inherentes a la intervención; b) las consecuencias previsibles de orden somático o psicológico; c) las repercusiones que pueda suponer en su vida personal, familiar o profesional (por ejemplo, disminución de ingresos por no poder trabajar); y d) los beneficios que con el trasplante se espera que conseguirá el receptor (art. 10 LAP).

La información no debe limitarse a un acto puntual, sino que debe constituir un proceso de una duración suficiente para favorecer su asimilación, la reflexión, la consulta a terceros y, en definitiva, una decisión sosegada y madura. Hay que contestar a todas las preguntas que se haga el potencial donante e, incluso, hay que sugerirlas y estimular al donante a plantearlas.

Por otro lado, debe tratarse de un órgano (o de parte de él), cuya extracción sea compatible con la vida y cuya función pueda ser compensada por el organismo del donante de forma adecuada y suficientemente segura. Normalmente se tratará de órganos dobles y no vitales (riñón, pulmón) o partes de él, cuando ello no impida la funcionalidad del resto. Preferentemente se trata de órganos de carácter regenerable (como el hígado).

El destino del órgano extraído será su transplante a una persona determinada, con el propósito de mejorar sustancialmente su esperanza o sus condiciones de vida, garantizándose el anonimato del receptor. Así pues, a diferencia de lo que sucede con las donaciones de fallecidos, en el caso de donaciones de vivos se cuenta ya con el paciente-receptor del órgano, y a partir de ahí se busca al donante más indicado. Al contrario de lo que sucede en otros países, en España el receptor del órgano puede ser cualquier persona $^{41}$.

Debido precisamente a los perjuicios que la extracción del órgano puede suponer para el donante vivo, ésta únicamente se justifica cuando no exista un órgano o tejido idóneo o disponible de una persona fallecida, ni tampoco ningún otro método alternativo que presente una eficacia comparable. Además, la extracción sólo podrá realizarse para el beneficio terapéutico del destinatario, es decir, con el propósito de favorecer la salud o las condiciones de vida de su receptor, y no será posible llevarla a cabo si existe un alto riesgo para la salud y la vida del donante ${ }^{42}$. Además, la extracción de órganos de donantes vivos se limitará a situaciones en las que puedan esperarse grandes posibilidades de éxito del trasplante.

${ }^{41}$ En otros países está más limitado el ámbito de posibles receptores (familia biológica $\mathrm{u}$ otras personas pertenecientes al círculo íntimo del donante). Con ello se trata de evitar motivaciones ocultas (pagos encubiertos, etc.). Cfr. ROMEO CASABONA, «Los principios jurídicos aplicables a los trasplantes de órganos y tejidos», pp. 22 y s.

${ }^{42}$ A este respecto, cfr. art. 19.1 CDHB ( «La extracción de órganos o de tejidos para trasplantes sólo podrá efectuarse de un donante vivo en interés terapéutico del receptor y cuando no se disponga del órgano o del tejido apropiados de una persona fallecida ni de un método terapéutico alternativo de eficacia comparable»). 
Para proceder a la extracción de órganos de donante vivo será necesario un segundo consentimiento, que deberá emitirse de un modo mucho más formal. Así, el interesado deberá otorgar por escrito su consentimiento expreso ante el juez encargado del registro civil de la localidad de que se trate. Se requiere, pues, la intervención judicial, que valora la capacidad del donante para consentir, así como sus circunstancias personales, para asegurarse de que la decisión es realmente libre.

Además del donante y el juez, también deberán estar presentes en ese momento el médico que ha de efectuar la extracción, el médico que haya acreditado el estado de salud física y mental del donante, el médico responsable del trasplante y la persona a la que corresponda dar la conformidad para la intervención, según figure en el documento de autorización del centro.

El documento de cesión donde se manifiesta la conformidad del donante será firmado por el interesado, el médico que ha de ejecutar la extracción y los demás asistentes. Cualquiera de ellos podrá oponerse eficazmente a la donación si albergan duda sobre que el consentimiento del donante se ha manifestado de forma expresa, libre, consciente y desinteresada.

Por otro lado, será necesario un informe obligatorio del Comité de Ética del hospital trasplantador. Este informe hará referencia a las posibilidades de éxito del trasplante y al libre consentimiento del donante, en cuanto a su forma de expresión, voluntariedad, motivación o libre determinación. También podrá valorar si el donante ha recibido una información adecuada para poder tomar una decisión y si esa información se ha transmitido de una forma entendible por éste.

Entre la firma del documento de cesión del órgano y su extracción, deberán transcurrir al menos veinticuatro horas, pudiendo el donante revocar su consentimiento en cualquier momento antes de la intervención sin sujeción a formalidad alguna. Por lo tanto, como apuntaba más arriba, transcurrido dicho plazo y antes de dar comienzo al acto de extracción, el donante deberá ratificar su consentimiento, si bien puede tratarse de un consentimiento tácito, por ejemplo, presentándose en el hospital para someterse a la intervención.

\subsubsection{LA DONACIÓN DE CÉLULAS Y TEJIDOS}

Aunque la donación de órganos o de sus partes y la donación de tejidos y células se basan en los mismos principios, existen ciertos elementos que los diferencian, y de hecho se regulan en normas diferentes. La donación de tejidos humanos se rige por lo dispuesto en el Real Decreto 1301/2006, de 10 de noviembre, por el que se establecen las normas de calidad y seguridad para la donación, la obtención, la evaluación, el procesamiento, la preservación, el almacenamiento y la distribución de células y tejidos humanos y se 
aprueban las normas de coordinación y funcionamiento para su uso en humanos ${ }^{43}$.

Este Real Decreto se aplica a todos los tejidos y células humanas, incluyendo las células progenitoras hematopoyéticas de sangre periférica, cordón umbilical o médula ósea; las células reproductoras, excepto en los aspectos regulados en la Ley 14/2006, de 26 de mayo, sobre técnicas de reproducción humana asistida; las células y tejidos fetales, y las células troncales adultas y embrionarias cuando su finalidad sea el uso terapéutico o la aplicación clínica. Quedan excluidos la sangre y los productos sanguíneos, a excepción de las células progenitoras hematopoyéticas y los órganos humanos, los cuales se rigen por su normativa específica.

Al igual que sucede con la donación de órganos, es necesario diferenciar entre los tejidos provenientes de un donante fallecido o de un donante vivo. Del primero de los casos se ocupa el art. 8 Real Decreto 1301/2006, según el cual, «la obtención de tejidos y células de personas fallecidas podrá realizarse en el caso de que no hubieran dejado constancia expresa de su oposición, según lo dispuesto en el artículo 11 LAP. En el caso de que se trate de menores o personas incapaces de consentir, la oposición a la donación podrá hacerse constar por quienes hubieran ostentado en vida de aquellos su representación legal» ${ }^{44}$ (art. 8.1).

La obtención de células y tejidos se realizará tras la correspondiente certificación de la muerte y la práctica de las diligencias policiales y judiciales si las hubiera (art. 8.4). Además, se deberá facilitar a los familiares y allegados información sobre la necesidad, naturaleza y circunstancias de la obtención, especificando qué procedimientos de restauración y conservación del cadáver y prácticas de sanidad mortuoria se llevarán a cabo (art. 8.3).

Por su parte, el art. 7 Real Decreto 1301/2006 dispone que la obtención de tejidos humanos de un donante vivo mayor de edad y plenamente capaz requiere que éste haya sido previamente informado de las consecuencias de su decisión y otorgue su consentimiento. La información que recibirá el donante del médico que vaya a realizar la extracción o sea responsable de ésta debe cubrir el objetivo y la naturaleza de la obtención de las células y

\footnotetext{
${ }^{43}$ Mediante este Real Decreto se incorpora al ordenamiento jurídico español la Directiva 2004/23/CE, así como la Directiva 2006/17/CE de la Comisión, de 8 de febrero de 2006, por la que se aplica la Directiva 2004/23/CE.

Por otro lado, esta norma deroga el Real Decreto 411/1996, de 1 de marzo, por el que se regulan las actividades relativas a la utilización de tejidos humanos.

${ }^{44} \mathrm{El}$ art. $11 \mathrm{LAP}$ se ocupa de las instrucciones previas. Según su apartado primero, «por el documento de instrucciones previas, una persona mayor de edad, capaz y libre, manifiesta anticipadamente su voluntad, con objeto de que ésta se cumpla en el momento en que llegue a situaciones en cuyas circunstancias no sea capaz de expresarlos personalmente, sobre los cuidados y el tratamiento de su salud o, una vez llegado el fallecimiento, sobre el destino de su cuerpo o de los órganos del mismo (...)».
} 
tejidos; sus consecuencias y riesgos; las pruebas analíticas que se han de realizar; el registro y protección de los datos; y los fines terapéuticos. Asimismo se informará de las medidas de protección aplicables al donante y de los beneficios que con el uso del tejido o grupo celular extraído se espera que haya de conseguir el receptor.

Resulta igualmente de interés prestar una especial atención a la cuestión de la obtención de células y tejidos de menores de edad e incapaces, si bien aquí no es posible más que apuntar algunas cuestiones, las cuales requieren indudablemente un análisis más detenido del que ahora se puede ofrecer. Según el Real Decreto 1301/2006, no podrán obtenerse tejidos humanos de personas menores de edad o personas que, por deficiencias psíquicas, enfermedad mental, incapacitación legal o cualquier otra causa, no puedan otorgar su consentimiento (art. 7.1.IV). Ello se debe a que el acto de donación de un tejido para su extracción en vida, a diferencia de lo que ocurre en los actos médicos, constituye una conducta de la que ningún beneficio directo deriva para el disponente a la vez que le causa un daño a su salud, por mínimo que éste sea, y a su integridad física, daño especialmente grave si tenemos en cuenta que estamos ante personas (en el caso de los menores de edad) que aún se encuentran en fase de desarrollo biológico y ello podría entrañar mayores riesgos para su desarrollo fisiológico y psíquico ${ }^{45}$.

No obstante, esta norma permite obtener materiales biológicos de tales sujetos «cuando se trate de residuos quirúrgicos o de progenitores hematopoyéticos u otros tejidos o grupos celulares reproducibles cuya indicación terapéutica sea o pueda ser vital para el receptor. En estos casos, el consentimiento será otorgado por quien ostente la representación legal» (art. 7.1.IV in fine). En todo lo no dispuesto en el art. 7, la obtención de células y tejidos de un donante vivo se regirá por lo dispuesto en la LAP.

Como ha manifestado la doctrina, la posibilidad de que los menores de edad $^{46}$ e incapacitados sean objeto de extracción de órganos o tejidos, incluso cuando se trata de situaciones extremas en las que éstos serían los únicos donantes válidos para llevar a cabo un trasplante en beneficio de un tercero (con el que estarían estrechamente vinculados), constituye una de las cuestiones más delicadas y complejas que la cirugía sustitutiva ha suscitado, y sobre la cual en la actualidad aún no existe una solución válida que merezca

${ }^{45}$ Carlos María Romeo Casabona, Los trasplantes de órganos. Informe y documentación para la reforma de la legislación española sobre trasplante de órganos, Bosch, Barcelona, 1978, p. 163.

${ }^{46}$ El término menor de edad debe entenderse como persona de edad inferior a 18 años, por lo que no es posible, a nuestro juicio, extender la capacidad de consentir una extracción de tejidos a menores de edad emancipados. Vid. a este respecto, en el mismo sentido, Víctor Angoitia Gorostiaga, «Los tejidos y los bancos de tejidos», en Carlos María Romeo CASABONa (coord.), El nuevo régimen jurídico de los trasplantes de órganos y tejidos, Comares, Granada, 2005, pp. 263 y ss. 
un incondicional apoyo desde una perspectiva ética y jurídica ${ }^{47}$. Si bien tradicionalmente se ha aceptado que se prohíba de forma absoluta la extracción de órganos de menores e incapacitados, la tendencia ha sido mucho más permisiva en lo que respecta a la obtención de cierto tipo de tejidos (debe tratarse de tejidos regenerables $)^{48}$, y siempre que se cumplan una serie de condiciones (por ejemplo, que exista un vínculo genético entre donante y receptor) ${ }^{49}$.

La primera cuestión que habría que analizar es el acomodo de esta previsión del Real Decreto con lo dispuesto en la Ley 30/1979, así como su compatibilidad con lo establecido en los arts. 155 y $156 \mathrm{CP}$, anteriormente mencionados. No debemos olvidar que el RD 1301/2006 es un mero reglamento, por lo que debe adecuarse a lo dispuesto en la Ley de referencia, en este caso la Ley 30/1979 ${ }^{50}$. Y la Ley 30/1979 se muestra tajante cuando en

${ }^{47}$ Vid. al respecto, Víctor Angoitia Gorostiaga, «El Convenio del Consejo de Europa para la protección de los derechos humanos y de la dignidad del ser humano, con respecto a las aplicaciones de la Biología y de la Medicina: Convenio sobre los derechos humanos y la biomedicina y el protocolo adicional sobre trasplante de órganos y tejidos de origen humano», en Carlos María Romeo CASABONa (coord.), El nuevo régimen jurídico de los trasplantes de órganos y tejidos, Comares, Granada, 2005, pp. 105 y ss.

${ }^{48}$ Según el Informe Explicativo al CDHB, por tejido regenerable se entiende «aquél capaz de reconstituir su masa y sus funciones tras una extracción parcial» (punto 123).

${ }^{49}$ Según el punto 125 del Informe Explicativo del CDHB, «el principio de ayuda mutua entre parientes de primer grado, sujeto a ciertas condiciones, puede justificar una excepción a la prohibición de extracción, encaminada a proteger a las personas incapaces de otorgar su consentimiento. Esta excepción a la regla general está cualificada por una serie de condiciones estipuladas en el artículo 20 para proteger a la persona incapaz de otorgar su consentimiento, que pueden ser completadas por la legislación nacional».

${ }^{50}$ Aunque esta Ley se refiere a la extracción y trasplante de órganos, se ha venido entendiendo por la doctrina de forma pacífica que lo establecido en ella es igualmente aplicable a la extracción y trasplante de otros tejidos. $\mathrm{O}$ lo que es lo mismo, el término órgano debe entenderse aquí de forma amplia. De hecho, la disposición adicional segunda de esta Ley únicamente excluye de su ámbito de aplicación a la sangre humana y sus derivados, a la vez que establece una previsión particular para la córnea y «otros tejidos».

Cfr. a este respecto, Romeo CASABONA, «Los principios jurídicos aplicables a los trasplantes de órganos y tejidos», p. 67; Víctor Angoitia GorostiagA, «Los tejidos y los bancos de tejidos», pp. 251 y s., Daniel García SAN José, «De vuelta con las células madre: el marco europeo de la clonación humana y los bancos de cordones umbilicales», Revista de Derecho Comunitario Europeo, n. ${ }^{\circ} 24$ (2006), p. 486, nota 13; David LARIos RisCo, «Donación y uso privativo de la sangre del cordón umbilical: aspectos jurídicos», Derecho y Salud, n. 2 (2007), p. 187.

Además, el propio Real Decreto 1301/2006 expresamente reconoce en su exposición de motivos que para su elaboración se ha tenido en cuenta la Ley 30/1979, y así lo entiende también la LIB cuando en su art. 1.4 dispone que quedan excluidas de su ámbito de aplicación las implantaciones de órganos, tejidos y células de cualquier origen que se regirán por lo establecido en la Ley 30/1979, de 27 de octubre, sobre extracción y trasplante de órganos; y en la Disposición adicional primera, según la cual «la utilización con fines terapéuticos de cualquier material biológico de origen humano a los que hace referencia esta Ley, se regirá, según corresponda por la Ley 30/1979, de 27 de octubre, sobre extracción y trasplante de órganos». 
su art. 4 establece el requisito (sin excepciones) de la mayoría de edad del donante, a la vez que afirma con rotundidad que «no podrá obtenerse ningún tipo de órganos de personas que, por deficiencias psíquicas o enfermedad mental o por cualquier otra causa, no puedan otorgar su consentimiento expreso, libre y consciente ${ }^{51}$. No obstante, esta Ley debe aplicarse de conformidad con lo establecido en el Convenio del Consejo de Europa, de 4 de abril de 1997, sobre Derechos Humanos y Biomedicina (CDHB), cuya aprobación es posterior, y expresamente admite esta posibilidad, en los términos en los que me referiré posteriormente.

En efecto, los tratados internacionales (como es el caso del CDHB) se configuran como derecho interno y podrán ser directamente aplicados (al menos, aquellas disposiciones de éstos con eficacia directa) ${ }^{52}$ una vez que éstos han sido publicados en el $\mathrm{BOE}^{53}$. De esta forma, si un tratado internacional incorporado al ordenamiento jurídico español a través del correspondiente instrumento de ratificación fuera contrario a una disposición normativa existente sobre esa misma materia, se plantea la duda acerca de la disposición aplicable. Tal y como señala la doctrina de forma mayoritaria, los tratados internacionales suscritos por España son normas legales jerárquicamente inferiores a la Constitución, pero superiores a las leyes ${ }^{54}$. De esta manera, en caso de conflicto entre tratado y ley a la hora de su potencial apli-

${ }^{51}$ Antes de la aprobación y entrada en vigor en el ordenamiento jurídico español del CDHB, la doctrina ya había manifestado tener serias dudas sobre la legalidad de algunos preceptos del Real Decreto 411/1996 relativos a esta misma cuestión. Cfr. Víctor ANGOITIA Gorostiaga, «Los tejidos y los bancos de tejidos», p. 251, nota 9.

${ }^{52}$ Las disposiciones de un tratado con eficacia directa (self-executive) son directamente aplicables por los poderes públicos de los Estados Parte sin que sea necesaria realizar ningún tipo de actuación previa. Se trata de aquellas disposiciones que son lo suficientemente claras como para poder pasar a formar parte del ordenamiento jurídico interno de forma automática. Vid. Sergio Romeo Malanda, «Relación del presente Convenio con otras disposiciones (Capitulo IX)», en Carlos María Romeo Casabona (ed.), El Convenio de Derechos Humanos y Biomedicina: su entrada en vigor en el ordenamiento jurídico español, Cátedra de Derecho y Genoma Humano-Comares, Bilbao-Granada, 2002, pp. 415 y ss; Thomas BUERGENTHAL, «Self-executing and non-self-executing treaties in national and international law», Recueil des Cours de l'Academie de Droit International, Tomo 235 (1992), pp. 313-400.

La calificación de una disposición de un tratado internacional como de eficacia directa o no es competencia, en nuestro ordenamiento jurídico, de los tribunales ordinarios. Cfr. Itziar GómEZ FERNÁNDEZ, Conflicto y cooperación entre la Constitución española y el Derecho internacional, Tirant lo Blanch, Valencia, 2005, p. 151, con nota 256.

${ }^{53} \mathrm{El}$ instrumento de ratificación del CDHB se publicó en el BOE de 20 de octubre de 1999, y en él se fija como fecha de entrada en vigor en España el 1 de enero de 2000, momento en el cual pasa a formar parte del ordenamiento jurídico español.

${ }^{54}$ Vid. Javier RoldÁn BARBero, Las relaciones exteriores de España, Dykinson, Madrid, 2001, p. 252. 
cación en un supuesto concreto, debe prevalecer el texto del tratado ${ }^{55}$. Un tratado internacional aprobado de acuerdo con el procedimiento establecido en el art. $94.1 \mathrm{CE}^{56}$, posee fuerza activa frente a la ley (esto es, puede modificarla o derogarla), así como fuerza pasiva (en ningún caso podrá ser éste derogado por una ley $)^{57}$.

De acuerdo con ello, en caso de conflicto entre el CDHB y la Ley 30/1979 en lo referido a la donación de células y tejidos regenerables por parte de menores e incapaces, aquél será de aplicación preferente ${ }^{58}$. Este conflicto ha de ser dirimido por la jurisdicción ordinaria mediante la búsqueda, en primer término, de una interpretación de la Ley acorde con el tratado y, de resultar esto imposible, mediante la inaplicación de la Ley ${ }^{59}$.

${ }^{55}$ Remedio SÁnchez Ferriz, El estado constitucional y su sistema de fuentes, 2. ${ }^{\text {a }}$ edición, Tirant lo Blanch, Valencia, 2002, p. 402. En cualquier caso, estos tratados constituyen un estándar mínimo susceptible de ser mejorado o concretado por el derecho interno, de tal manera que la regla de prevalencia de los tratados cederá para aplicar preferentemente la ley interna más favorable. En el caso del CDHB, dada su naturaleza y objetivos, la ley interna más favorable será aquella que resulte más protectora de los derechos de las personas.

${ }^{56}$ Según el art. 94.1 CE, «La prestación del consentimiento del Estado para obligarse por medio de Tratados o convenios requerirá la previa autorización de las Cortes Generales, en los siguientes casos: (...) e) Tratados o convenios que supongan modificación o derogación de alguna Ley o exijan medidas legislativas para su ejecución». Cfr. Instrumento de ratificación del CDHB.

${ }^{57}$ Vid. SÁNCHEZ FERRIZ, El estado constitucional y su sistema de fuentes, p. 403; RoLDÁN BARBERO, Las relaciones exteriores de España, p. 253. Esto se debe a que las disposiciones de un tratado «sólo podrán ser derogadas, modificadas o suspendidas en la forma prevista en los propios Tratados o de acuerdo con las normas generales del Derecho Internacional» (art. 96.1 CE). Del mismo modo, el art. 96.2 CE establece que «para la denuncia de los Tratados y convenios internacionales se utilizará el mismo procedimiento previsto para su aprobación en el artículo 94». Por el contrario, un tratado sí puede conllevar «modificación o derogación de alguna Ley» (art. 94.1.e CE).

La modificación del CDHB exige, pues, el cumplimiento de las normas de derecho internacional aplicables al efecto, bien acudiendo al procedimiento de enmiendas al mismo recogido en su art. 32, bien a través de su denuncia (art. $37 \mathrm{CDHB}$ ), bien introduciendo alguna reserva (art. $36 \mathrm{CDHB}$ ), tal y como han hecho, por cierto, algunos estados. Por ejemplo, Dinamarca ha presentado una reserva al CDHB, oponiéndose a la limitación del receptor a la condición de hermano o hermana del donante, por excluirse de ese modo la posibilidad de que la médula del menor o incapacitado sea trasplantada a su padre o a su madre.

${ }^{58}$ Para mantener la prohibición de utilizar a personas incapaces de prestar consentimiento válido como fuente de tejidos tras la ratificación del CDHB, un país debe formular una reserva, en los términos establecidos en el art. 36 de éste. Así lo hizo, por ejemplo, la República de Turquía, tal y como consta en el Instrumento de ratificación del mencionado tratado por parte del estado español: «Conforme al artículo 36 del Convenio, la República de Turquía se reserva el derecho a no aplicar lo dispuesto en el apartado 2 del artículo 20 del Convenio, que autoriza, en ciertas condiciones, la extracción de tejidos regenerables de una persona que no tenga capacidad para dar su consentimiento, ya que esta disposición es contraria a la prohibición establecida en el artículo 5 de la Ley número 2238, sobre extracción, preservación y trasplante de órganos y tejidos».

${ }^{59}$ ROLdÁn BARBERO, Las relaciones exteriores de España, p. 254. 
Las consideraciones anteriores son igualmente válidas en relación con normas jurídicas de rango inferior a la Ley. Así, si alguna disposición del Real Decreto 1301/2006 resultara contraria a lo dispuesto en el CDHB, las disposiciones controvertidas de dicho Real Decreto no serían aplicadas. Además, en este caso el Tribunal Supremo ha avalado el poder anulatorio que puede ejercer el juez ordinario en caso de contradicción de un Real Decreto con las disposiciones de un tratado ${ }^{60}$. No obstante, como decíamos anteriormente, esta decisión únicamente deberá adoptarse siempre que no resulte posible una interpretación de la norma interna conforme al tratado internacional.

Por otro lado, también hacíamos referencia a una posible incompatibilidad entre la regulación prevista en el art. 7 Real Decreto 1301/2006 y lo dispuesto en el Código penal en los arts. 155 y 156, relativos al consentimiento en el delito de lesiones. En efecto, en los arts. 147 y siguientes del Código penal se castiga a quien «causare a otro una lesión que menoscabe su integridad corporal o su salud física o mental». En principio, parece indudable que los actos dirigidos a obtener ciertos tejidos de una persona a través de procedimientos invasivos, especialmente cuando éstos no tienen una finalidad terapéutica directa para ella, supone una afectación a la integridad corporal, por lo que se integraría en el tipo del delito mencionado. Además, el Código penal se manifiesta claramente restrictivo en relación con el consentimiento en las lesiones, lo cual se traduce en una limitación de la autonomía de la voluntad, pues en su art. 155 establece que «en los delitos de lesiones, si ha mediado el consentimiento válida, libre, espontánea y expresamente emitido del ofendido, se impondrá la pena inferior en uno o dos grados». Es decir, que la aceptación del acto que genera las lesiones por parte del sujeto pasivo no evita el castigo del autor de éstas, aunque la pena impuesta será menor. Además, añade que «no será válido el consentimiento otorgado por un menor de edad o un incapaz». Esto es, cuando el sujeto pasivo sea menor de edad, la pena imponible no se verá atenuada.

Es cierto que el art. $156 \mathrm{CP}$ establece una regla especial. Así, dispone que «no obstante lo dispuesto en el artículo anterior, el consentimiento válida, libre, consciente y expresamente emitido exime de responsabilidad penal en los supuestos de trasplante de órganos efectuado con arreglo a lo dispuesto en la Ley (...) salvo que el consentimiento se haya obtenido viciadamente, o mediante precio o recompensa, o el otorgante sea menor de edad o incapaz; en cuyo caso no será válido el prestado por éstos ni por sus representantes legales» (la cursiva es nuestra). En definitiva, la extracción de órganos en vida con fines de donación no se castigará si ésta se produce de acuerdo con la legislación vigente. Ahora bien, se exige que el donante no sea menor de edad o incapaz, pues en tal caso, la extracción no puede ser

${ }^{60}$ STS (Sala 3. ${ }^{\text {a) }}$ de 24 de febrero de 1994. 
consentida ni por éstos ni por sus representantes legales. Ello supondría la comisión de un delito de lesiones por parte del facultativo que extrae el órgano o tejido (así como de quien autorizó dicha extracción en calidad de autor, bien como inductor, bien como cooperador necesario).

La primera cuestión que cabe plantearse es si esta regla excepcional del art. $156 \mathrm{CP}$ comprende también los trasplantes de células y tejidos, pues su tenor literal únicamente hace referencia al trasplante de órganos. Aplicar esta disposición al trasplante de materiales distintos de los órganos podría suponer la aplicación analógica de una disposición penal, lo cual resulta contrario al principio de legalidad penal ${ }^{61}$. Por el contrario, podría defenderse que el término «órgano» se emplea en el CP en un sentido amplio, incluyendo también los tejidos, de forma similar a como lo hace la Ley 30/1979 (interpretación lógico-sistemática). En cualquier caso, ello resulta intrascendente a nuestros efectos, pues en ambos casos el resultado es el mismo, la responsabilidad penal de quien procede a realizar una extracción de órganos de un menor de edad. En definitiva, se nos plantea la duda de cómo conjugar esta previsión legal con la norma que avala dicha extracción, esto es, el Real Decreto 1301/2006.

No es posible hacer un detallado análisis de esta cuestión ahora, pues ello excede el propósito de este trabajo. No obstante, sí es posible dejar planteadas algunas hipótesis. En principio, podrían ser de aplicación diversas instituciones jurídico-penales. Por ejemplo, la causa de justificación de ejercicio legítimo de un derecho, oficio o cargo (art. 20.7 CP), al existir una norma permisiva de la conducta (el Real Decreto 1301/2006, en relación con el referido art. 20.7 CP), frente a la norma prohibitiva del art. $155 \mathrm{CP}$. O la también causa de justificación de estado de necesidad (art. 20.5 CP), por la cual sería lícita la causación de un mal ajeno siempre que el mal causado no sea mayor que el que se trate de evitar. Sin embargo, esta última posibilidad presenta ciertos inconvenientes, pues la doctrina viene entendiendo que, además de los requisitos exigidos en el Código penal, el acto causante del daño no puede ser contrario a la dignidad de la persona, la cual se afectaría cuando ésta es sometida sin su consentimiento a una intervención quirúrgica con el fin de extraer un órgano o tejido ${ }^{62}$. También podría mantenerse que la con-

${ }^{61}$ Cfr. Sergio Romeo Malanda, «Las eximentes por analogía en el Código penal español de 1995. Especial referencia a la aplicación analógica de la indicación criminológica del aborto», Revista de Derecho Penal y Criminología, n. 16 (2005), pp. 169 y ss.

${ }^{62} \mathrm{La}$ doctrina entiende de forma mayoritaria que el estado de necesidad será una causa de justificación siempre que el mal causado sea menor que el que se trate de evitar. En nuestro ordenamiento jurídico es indudable, en relación con el supuesto planteado, que la vida humana es un bien superior al de la integridad corporal y al de libertad. Detener el análisis en este punto nos llevaría a entender que la conducta descrita está justificada. Ahora bien, como propone José Cerezo Mir, Curso de Derecho penal español. Parte General. II. Teoría jurídica del Delito, 6. ${ }^{\text {a }}$ edición, Tecnos, Madrid, 1998, pp. 268 y ss, no es posible considerar lícitas, aquellas conductas que supongan un grave atentado a la dignidad de la persona 
ducta de obtención de un tejido de un sujeto menor de edad o incapaz no sería sancionable si se realiza de acuerdo con las previsiones legales por tratarse de una conducta atípica, esto es, dicho comportamiento no supondría la comisión de un delito de lesiones al no ser la conducta objetivamente imputable a quien la realiza, pues nos encontraríamos ante un comportamiento socialmente adecuado ${ }^{63}$. Por una parte, la posibilidad de extraer cierto tipo de tejidos de sujetos menores o incapaces, cuando ello pueda servir para salvar la vida de otra persona, es una práctica admitida socialmente (por supuesto, siempre que se respeten ciertas garantías, concretadas en los requisitos legalmente establecidos), no sólo dentro de nuestro país sino también en el ámbito internacional. Por otro lado, la lesión que se causa al donante resultaría tan mínima que permitiría mantener la atipicidad de la conducta con fundamento en el principio de insignificancia ${ }^{64}$. Así pues, la exclusión de la tipicidad penal se produciría en estos casos, no porque no exista una relación causal entre una lesión penalmente relevante y la conducta de su autor, sino por la irrelevancia penal de la lesividad del hecho, al ser éste socialmente admitido o insignificante, atendido el contexto en que se produce ${ }^{65}$. Sin embargo, un importante sector doctrinal entiende que el criterio de la adecuación social como causa de exclusión de la tipicidad de la conducta, así como el denominado principio de insignificancia, son sumamente imprecisos y afectarían, por ello, gravemente a la seguridad jurídica ${ }^{66}$.

humana. En el supuesto mencionado se está utilizando al ser humano como un simple instrumento para la consecución de otros fines y ello implica un grave atentado contra su dignidad. Por ello, introduce el citado autor una restricción en el criterio de la opinión dominante: «el estado de necesidad será una causa de justificación cuando el mal causado sea menor que el que se trataba de evitar siempre que la conducta realizada no implique una infracción grave del respeto debido a la dignidad de la persona humana». Cfr. igualmente, Angoitia Gorostiaga, «Los tejidos y los bancos de tejidos», p. 262.

A la misma conclusión llegan, pero por considerar que el mal causado es mayor que el que se evita, Santiago Mir PUIG, Derecho Penal. Parte General, 5. a edición, PPU, Barcelona, 1998, pp. 471 y ss.; Fermín Morales PraTs, «Artículo 20.5», en Gonzalo Quintero Olivares (ed.)/Fermín Morales Prats (coord.), Comentarios al Nuevo Código Penal, 2. ${ }^{\text {e edición, }}$ Aranzadi, Pamplona, 2001, pp. 180 y ss.

${ }^{63}$ Cfr. Angoitia Gorostiaga, «Los tejidos y los bancos de tejidos», p. 262.

${ }^{64}$ La médula ósea puede ser obtenida a través de diferentes métodos ambulatorios y no requieren de hospitalización. Angoitia Gorostiaga, «Los tejidos y los bancos de tejidos», p. 260, reconoce que la extracción de médula ósea es una intervención sin riesgos reseñables y de la que ningún perjuicio puede derivarse para la salud presente o futura del menor.

${ }^{65}$ Cfr. Santiago MiR PuIG, «Significado y alcance de la imputación objetiva en Derecho penal», Revista Electrónica de Ciencia Penal y Criminología (en línea), 2003, núm. 05-05, p. 05:1-05:19. Disponible on line: <http://criminet.ugr.es/recpc/recpc05-05.pdf>, p. 16; Diego-Manuel LuZón PeÑa, Curso de Derecho Penal. Parte General I, Editorial Universitas, Madrid, 1996, pp. 561 y s., y 565 y s.

${ }^{66}$ Vid. José Cerezo Mir, Curso de Derecho penal español. Parte General. II. Teoría jurídica del Delito, 6. a edición, Tecnos, Madrid, 1998, pp. 98 y s. 
Por otra parte, la nueva regulación contenida en el Real Decreto 1301/2006 conlleva una modificación sustancial de la normativa precedente (art. 7 Real Decreto 411/1996), pues allí únicamente se preveía esta excepción en relación con los menores de edad (no con los adultos sin capacidad de obrar), y exclusivamente para las situaciones en que existiera relación genética entre donante y receptor. Además, la nueva regulación no recoge ciertas garantías previstas en la normativa derogada, como por ejemplo, la autorización judicial.

De este modo, esta nueva regulación presenta serias dudas por lo que respecta a su acomodo al Convenio sobre Derechos Humanos y Biomedicina, que vincula al legislador español desde su entrada en vigor en nuestro ordenamiento jurídico en enero de 2000. De acuerdo con el art. 20 CDHB,

«1. No podrá procederse a ninguna extracción de órganos o de tejidos de una persona que no tenga capacidad para expresar su consentimiento conforme al artículo 5 .

2. De modo excepcional y en las condiciones de protección previstas por la ley, la extracción de tejidos regenerables de una persona que no tenga capacidad para expresar su consentimiento podrá autorizarse si se cumplen las condiciones siguientes:

i. si no se dispone de un donante compatible capaz de prestar su consentimiento,

ii. si el receptor es hermano o hermana del donante,

iii. si la donación es para preservar la vida del receptor,

iv. si se ha dado específicamente y por escrito la autorización prevista en los apartados 2 y 3 del artículo 6, según la ley y de acuerdo con la autoridad competente,

v. si el donante potencial no expresa su rechazo a la misma.»

Así pues, si bien el CDHB no supone impedimento alguno para extender la excepción de donar tejidos humanos a los incapaces, además de a los menores de edad, sí que exige el cumplimiento de ciertos requisitos, los cuales son claramente obviados por la nueva legislación que estamos analizando. En concreto:

a) el Real Decreto 1301/2006 no requiere la falta de un donante compatible capaz de prestar su consentimiento, sino únicamente que el tejido que va a donarse tenga una utilidad terapéutica de carácter vital para el receptor (de forma coincidente, aquí sí, con lo establecido en el punto iii del art. 20.2 CDHB);

b) el Real Decreto 1301/2006 no impone la restricción prevista en el CDHB de que el receptor del tejido sea hermano o hermana del donante, como hemos dicho que sí hacía el derogado Real Decreto 411/1996 (si bien es cierto que no limitado a los hermanos sino a 
quienes tuvieran una relación genética, por lo tanto, extensible a toda la familia biológica) ${ }^{67}$;

c) el Real Decreto 1301/2006 no exige la autorización por parte de una autoridad, además de la del representante legal del menor o incapaz ${ }^{68}$. Dicha autoridad debería ser el juez encargado del registro civil, por coherencia con lo establecido en relación con la donación de órganos, a la que expresamente se remitía el Real Decreto 411/1996, en su art. 7.369;

d) finalmente, el Real Decreto 1301/2006 no establece previsión alguna respecto a la voluntad del donante, pues no puede olvidarse que el menor puede tener suficiente capacidad de juicio, o el sujeto incapacitado puede estar atravesando un periodo de lucidez, o simplemente, su grado de incapacidad no le impide entender la naturaleza de la intervención a la que se le quiere someter. De hecho, en relación con los menores de edad, el Real Decreto 411/1996 establecía de forma expresa la obligación de oír al menor antes de tomar la decisión, obligación que, por otro lado, viene impuesta con carácter general en el art. 9.1 de la Ley Orgánica 1/1996, de 15 de enero, de Protección Jurídica del Menor.

Se plantea, en consecuencia, la cuestión de cómo hay que valorar esta falta de conexión o concordancia entre dos texto legales vigentes en nuestro ordenamiento jurídico, el CDHB y el Real Decreto 1301/2006. Tal y como señalamos al respecto más arriba, en caso de conflicto será de aplicación el

${ }^{67}$ En relación con la exigencia de que el beneficiario sea hermana o hermano, el punto 128 del Informe Explicativo del CDHB señala que «esta restricción pretende impedir que tanto la familia como los médicos se excedan en la búsqueda de un donante a cualquier precio, aun cuando el grado de parentesco sea lejano y las probabilidades de éxito en el transplante no sean muy altas por incompatibilidad de tejidos».

Sin embargo, algún autor entiende que este precepto resulta demasiado restrictivo, pues impediría la donación de medula ósea de un menor incapacitado cuando el destinatario fuera su padre o su madre; y al mismo tiempo, al permitir la nueva regulación la obtención de tejidos procedentes de sujetos incapacitados, podría igualmente suceder que éstos tuvieran descendencia que pudiera beneficiarse de una donación de su médula ósea. Cfr. ANGOITia Gorostiaga, «El Convenio del Consejo de Europa para la protección de los derechos humanos y de la dignidad del ser humano, con respecto a las aplicaciones de la Biología y de la Medicina: Convenio sobre los derechos humanos y la biomedicina y el protocolo adicional sobre trasplante de órganos y tejidos de origen humano», pp. 123 y s.

${ }^{68}$ Según el Informe Explicativo del CDHB, «la intervención de esta institución (que puede ser un tribunal, un organismo cualificado profesionalmente, un comité de ética, etcétera) pretende garantizar que la decisión que se adopte sea imparcial» (punto 129).

${ }^{69}$ Este precepto exige autorización judicial para la extracción del tejido de un donante vivo (por remisión a la normativa sobre donación de órganos) «en el supuesto de que sea precisa una intervención quirúrgica» específicamente destinada a la obtención de dicho tejido.

Sobre la relevancia de la intervención judicial cuando están involucrados menores de edad, vid. Angoitia Gorostiaga, «Los tejidos y los bancos de tejidos», pp. 269 y ss. 
CDHB, pues éste goza de un rango normativo superior al Real Decreto. Ahora bien, también hay que tener en cuenta que el Real Decreto 1301/2006 no es incompatible con lo establecido en el CDHB, sino que simplemente no incluye ciertas disposiciones previstas en éste. Esto hace posible, a nuestro juicio, una interpretación y aplicación del Real Decreto 1301/2006 conforme al CDHB.

Así pues, puesto que ambos textos legales no entran en confrontación directa, la solución pasa por realizar un estudio integrado y coordinado de éstos, de tal forma que la regulación de la donación de células y tejidos con fines terapéuticos por parte de menores de edad e incapaces no se contiene únicamente en el citado art. 7 Real Decreto 1301/2006, sino en éste en conjunción con el art. $20 \mathrm{CDHB}$. Además, habrá que tener igualmente en cuenta el resto del ordenamiento jurídico, el cual puede imponer ciertas actuaciones independientemente de que expresamente lo establezca o no el Real Decreto 1301/2006, por ejemplo respecto a la autonomía de los menores de edad $^{70}$.

Aún cabe hacer alguna consideración adicional por lo que respecta al requisito de la intervención de la «autoridad competente». El art. 7.3 Real Decreto 411/1996 exigía autorización judicial para la extracción del tejido de un donante vivo (por remisión a la normativa sobre donación de órganos) «en el supuesto de que sea precisa una intervención quirúrgica» específicamente destinada a la obtención de dicho tejido. Pero este precepto no se refería únicamente a los menores, sino a todos los donantes de tejidos. Este requisito, como decimos, ha sido obviado en el Real Decreto 1301/2006.

El CDHB señala en su art. 19.2 que el consentimiento «deberá ser expresa y específicamente otorgado, bien por escrito o ante una autoridad». Esto es, el CDHB no impone la intervención de la autoridad competente, sino que deja libertad a los Estados para decidir entre dicha intervención, o la consignación del consentimiento por escrito. En el caso que nos ocupa, el legislador parece haber optado por la consignación del consentimiento por escrito $^{71}$.

\footnotetext{
${ }^{70}$ Resulta evidente que la normativa sobre trasplantes no puede interpretarse al margen de las reglas generales sobre capacidad. Así, no dejan de ser de aplicación, por ejemplo, los arts. 154 y 162 Cc o la referida Ley Orgánica 1/1996. De este modo, en todo aquello que afecta a la propia personalidad del menor, aunque en él no exista la capacidad para realizar (con plena validez) los actos de que se trate, el representante legal ha de contar inexcusablemente con su consentimiento siempre que éste tenga suficiente capacidad natural de juicio, y en todo caso, si es mayor de 12 años. Vid. al respecto, Angoitia Gorostiaga, «Los tejidos y los bancos de tejidos», pp. 256 y ss., y 268.

${ }^{71}$ Art. 7.1.I Real Decreto 1301/2006: «La obtención de células y tejidos de una persona viva para su ulterior aplicación alogénica en seres humanos podrá realizarse si el donante es mayor de edad, cuenta con plena capacidad de obrar y estado de salud adecuado y ha prestado por escrito su consentimiento informado» (la cursiva es nuestra).
} 
No obstante, aunque el requisito de la intervención de la autoridad judicial no se haya previsto en relación con los adultos capaces, decisión que resulta acorde con el $\mathrm{CDHB}$, tal requisito sí que sería obligatorio cuando se trate de menores o incapaces. No es admisible, pues, la falta de concreción del legislador acerca de quién debe ser dicha autoridad, lo cual podría haber hecho, bien de forma expresa, bien por remisión a la legislación sobre trasplante de órganos, como hacía la norma derogada. En todo caso, por coherencia con lo establecido en la regulación sobre trasplante de órganos, dicha autoridad debería ser el juez encargado del registro civil ${ }^{72}$. Sin embargo, al no existir previsión legal alguna al respecto (al margen de la disposición general contenida en el CDHB), este requisito no puede ser exigido en la práctica, de tal modo que el estado español estaría contraviniendo una de las disposiciones del $\mathrm{CDHB}^{73}$.

Por otro lado, también cabe hacer alguna reflexión adicional sobre alguno de los requisitos recogidos en el Convenio (no así en el Real Decreto 1301/2006). Así, el art. 20.2.i requiere que no se disponga «de un donante compatible capaz de prestar su consentimiento». Para Angoitia Gorostiaga, «la indisponibilidad de un donante compatible con capacidad para consentir apunta, tanto al hecho de que, a pesar de todos los medios y recursos utilizados, familiares, amigos y donantes voluntarios sometidos a pruebas previas de compatibilidad, etc., sólo el menor o incapacitado se manifiesten como donantes válidos por razones de histocompatibilidad del preciado tejido que puede salvar la vida de su hermano o hermana, como, más penosamente, al supuesto de que existiendo otros donantes compatibles con capacidad para consentir, sin embargo no accedan, por las razones que fuere, a donar una porción de su médula ósea» ${ }^{74}$.

La importancia de este requisito se ve claramente en el punto 2.2 del Anexo V Real Decreto 1301/2006 («Procedimientos de donación, extracción de células y tejidos y su recepción en el establecimiento de tejidos»), establece que «los datos que se deben registrar en el establecimiento de tejidos (excepto en el caso de la donación de células reproductoras entre miembros de la pareja) serán, al menos, los siguientes: a) Consentimiento o autorización para la extracción, donde se consigne el propósito de utilización (uso terapéutico o investigación o ambos) y cualquier instrucción específica para su destrucción cuando no se utilicen para el propósito con el que se obtuvieron (...)».

${ }^{72}$ En este punto, el CDHB contiene una disposición de eficacia diferida, que requiere una concreción legislativa por parte de los estados.

${ }^{73}$ Sobre los efectos jurídicos del incumplimiento de las obligaciones asumidas en virtud del CDHB por un estado parte, vid. Romeo MALANDA, «Relación del presente Convenio con otras disposiciones (Capitulo IX)», pp. 418 y ss.

${ }^{74}$ Angoitia Gorostiaga, «El Convenio del Consejo de Europa para la protección de los derechos humanos y de la dignidad del ser humano, con respecto a las aplicaciones de la Biología y de la Medicina: Convenio sobre los derechos humanos y la biomedicina y el protocolo adicional sobre trasplante de órganos y tejidos de origen humano», p. 115. 
Por último, la obtención de los materiales biológicos oportunos deberá llevarse a cabo de forma que se garantice que la evaluación y selección de los donantes se realiza de acuerdo con los (exhaustivos) requisitos especificados en los anexos II (requerimientos clínicos para la evaluación de los donantes de células y tejidos), III (tests de laboratorio requeridos en la evaluación de los donantes), IV (selección y evaluación del donante de células reproductoras) y $\mathrm{V}$ (procedimientos de donación, extracción de células y tejidos y su recepción en el establecimiento de tejidos) del Real Decreto $1301 / 2006$.

\subsubsection{LA DONACIÓN DE SANGRE}

Según el art. 6 Real Decreto 1088/2005, «los candidatos a donantes de sangre recibirán información previa por escrito y en lenguaje comprensible, como mínimo, acerca de las condiciones y actividades que excluyen de la donación y de la importancia de no dar sangre si le son aplicables algunas de ellas. La información mínima que se deberá proporcionar es la recogida en el anexo I.A.».

Además, los donantes deberán cumplir los requisitos contenidos en el Anexo II.A Real Decreto 1088/2005 para poder consentir la extracción de sangre y su donación. En concreto, deben tener una edad comprendida entre los 18 y 65 años y el peso corporal debe ser mayor de $50 \mathrm{~kg}$. Igualmente, deben cumplirse ciertos requerimientos de carácter médico (en relación con el pulso y la tensión arterial, o el nivel de hemoglobina, proteínas o de plaquetas en sangre). Al referirse exclusivamente a los mayores de dieciocho años, ninguna persona de edad inferior puede ser donante. La exigencia de dicha edad se debe a la necesidad de que el donante posea ciertas condiciones físicas, no a que se requiera una plena capacidad de obrar ${ }^{75}$.

El intervalo mínimo entre dos extracciones consecutivas de sangre total, salvo circunstancias excepcionales, no podrá ser inferior a dos meses. El número máximo de extracciones anuales no podrá superar el número de cuatro para los hombres y de tres para las mujeres. Además, la cantidad de sangre extraída en cada ocasión deberá tener en cuenta el peso del donante, y no deberá superar el 13\% del volumen sanguíneo teórico del donante.

Por ello, este mismo autor afirma en otro lugar del mismo trabajo que «incluso en el supuesto de que tal posibilidad [la obtención de ciertos tejidos de menores e incapaces] se acoja sólo excepcionalmente y rodeada de toda clase de garantías (...), será imposible dejar de reconocer la hipocresía de una sociedad que permite en menores e incapacitados lo que en ningún caso autoriza respecto a los adultos plenamente capaces».

${ }^{75}$ María José SANTOS MoRón, Incapacitados y derechos de la personalidad: tratamientos médicos, honor, intimidad e imagen, Escuela Libre Editorial, Madrid, 2000, p. 106. 


\subsubsection{LA DONACIÓN DE MATERIAL FETAL}

La LIB, en la misma línea que la derogada Ley 42/1988, de 28 de diciembre, de donación y utilización de embriones y fetos humanos o de sus células, tejidos u órganos, a la cual sustituye, permite la obtención y utilización de materiales biológicos de embriones y fetos humanos con fines terapéuticos ${ }^{76}$ (por ejemplo, ciertos órganos o tejidos pueden servir para trasplante o cirugía reparadora).

La donación de embriones o fetos humanos o de sus estructuras biológicas para las finalidades previstas en esta Ley (en la que se incluye, como decíamos, la finalidad terapéutica) deberá cumplir los siguientes requisitos (art. 29.1 LIB):

a) Que el donante o donantes de los embriones o los fetos hayan otorgado previamente su consentimiento de forma expresa y por escrito. Si alguno de aquéllos fuera menor no emancipado o estuviera incapacitado, será necesario además el consentimiento de sus representantes legales.

b) Que el donante o los donantes o, en su caso, sus representantes legales hayan sido informados, previamente a que otorguen su consentimiento, de los fines a que puede servir la donación, de sus consecuencias, así como de las intervenciones que se vayan a realizar para extraer células o estructuras embriológicas o fetales, de la placenta o las envolturas y de los riesgos que pueden derivarse de dichas intervenciones.

c) Que se haya producido la expulsión, espontánea o inducida, en la mujer gestante de dichos embriones o fetos, y no haya sido posible mantener su autonomía vital.

En el caso de que hubieren fallecido las personas de las que provienen los embriones o los fetos, será necesario que no conste su oposición expresa. Si el fallecido fuera menor de edad no emancipado o una persona incapacitada, será precisa la autorización de quienes ejercieran, en vida de aquéllos, su representación legal (art. 29.2 LIB).

${ }^{76}$ Cfr. art. 28.1 LIB. En relación con esta cuestión, el art. 28.2 LIB dispone que «la interrupción del embarazo nunca tendrá como finalidad la donación y la utilización posterior de los embriones o fetos o de sus estructuras biológicas. El procedimiento y modo de la práctica de la interrupción del embarazo estarán únicamente supeditados a las exigencias y limitaciones legales y a las características y circunstancias que presente aquél. Los profesionales integrantes del equipo médico que realice la interrupción del embarazo no intervendrán en la utilización de los embriones o de los fetos abortados ni de sus estructuras biológicas $(\ldots) »$. 


\subsection{Utilización de materiales biológicos con fines terapéuticos. Requisi- tos respecto al receptor}

Al analizar la cuestión del destino de materiales biológicos con fines terapéuticos, hay que tener en cuenta una doble perspectiva: por una parte, la autorización del sujeto fuente de la muestra y las condiciones para que una muestra proveniente de un sujeto pueda emplearse con fines terapéuticos (en el propio individuo o en un tercero); y por otro lado, el consentimiento del receptor de las muestras para que éstas puedan ser utilizadas.

Por lo que respecta al sujeto fuente, la decisión relativa al uso del material en cuestión está directamente vinculada a su obtención, por lo que en el momento de obtenerse la muestra y prestar su consentimiento, está autorizando su uso terapéutico posterior.

Por su parte, en relación con el sujeto receptor del material biológico, serán de aplicación las reglas generales contenidas en la LAP, especialmente aquellas referentes a la información y al consentimiento previo a todo acto médico. No obstante, leyes especiales pueden recoger alguna provisión específica, tal y como sucede en relación con la donación de sangre, tejidos u órganos para trasplante.

En relación con el trasplante de órganos, el art. 6 Ley 30/1979 únicamente ofrece unas previsiones muy generales, que no alteran la regla establecida en la LAP. Tan sólo la aclaran en relación con la información que debe transmitirse al paciente que va a recibir el órgano. En el mencionado precepto se dice que el receptor debe ser plenamente consciente del tipo de intervención que va a efectuarse, conociendo los posibles riesgos y las previsibles ventajas que, tanto física como psíquicamente, puedan derivarse del trasplante. Además, se añade que el consentimiento para la realización del trasplante deberá expresarse por escrito cuando se trate de un adulto jurídicamente responsable de sus actos, o por sus representantes legales, padres o tutores, en caso de pacientes con déficit mental o menores de edad (lo cual tampoco resulta novedoso). Como único elemento específico, la letra b del art. 6, establece que el receptor del órgano debe ser «informado de que se han efectuado en los casos precisos los necesarios estudios inmunológicos de histocompatibilidad u otros que sean procedentes, entre donante y futuro receptor, efectuados por un laboratorio acreditativo por el Ministerio de Sanidad y Consumo».

Esta regulación se completa con el art. 15 Real Decreto 2070/1999, que en la línea de la Ley 30/1979 establece que «el trasplante de órganos humanos sólo se podrá efectuar en centros autorizados para ello, con el consentimiento previo y escrito del receptor o sus representantes legales (...)» (apartado 1). «El documento en el que se haga constar el consentimiento informado del receptor comprenderá: nombre del centro sanitario, fecha de su autorización para hacer trasplantes y nombre del receptor y, en su caso, el de los representantes que autorizan el trasplante. El documento tendrá que ser firmado por el médico que informó al receptor y por éste mismo o sus repre- 
sentantes. El documento quedará archivado en la historia clínica del paciente y se facilitará copia del mismo al interesado» (apartado 2).

Además, de acuerdo con el art. 15.4 Real Decreto 2070/1999, el trasplante únicamente se realizará «si existen perspectivas fundadas de mejorar sustancialmente el pronóstico vital o las condiciones de vida del receptor, y de que se han realizado entre donante y receptor los estudios que sean técnicamente apropiados al tipo de trasplante que en cada caso se trate».

Por lo que respecta a la utilización de células y tejidos humanos, de acuerdo con el art. 26.5 Real Decreto 1301/2006, «para la aplicación de células y tejidos humanos se requerirá el consentimiento del receptor o de sus representantes legales según lo dispuesto en la Ley 41/2002, de 14 de noviembre ${ }^{77}$. Igualmente, debe tenerse en cuenta lo establecido en el art. 46.1 de la Ley 29/2006, de 26 de julio, de garantías y uso racional de los medicamentos y productos sanitarios, referido a los medicamentos de origen humano, según el cual, «los derivados de la sangre, del plasma y el resto de sustancias de origen humano (fluidos, glándulas, excreciones, secreciones, tejidos y cualesquiera otras sustancias), así como sus correspondientes derivados, cuando se utilicen con finalidad terapéutica, se considerarán medicamentos y estarán sujetos al régimen previsto en esta Ley, con las particularidades que se establezcan reglamentariamente según su naturaleza y características».

Por su parte, el art. 15 Real Decreto 1088/2005, exige siempre prescripción médica para la administración de sangre y sus componentes y añade que «siempre que sea posible, el médico que establezca la indicación recabará, después de explicarle los riesgos y beneficios de esta terapéutica, así como sus posibles alternativas, la conformidad del paciente, conforme a lo dispuesto en la Ley 41/2002, de 14 de noviembre, básica reguladora de la autonomía del paciente y de derechos y obligaciones en materia de información y documentación clínica (...)».

Además, tal y como recoge el art. 18.1 Real Decreto 1088/2005, antes de la administración de cualquier componente eritrocitario homólogo, al receptor se le realizarán pruebas de compatibilidad, excepto en los casos de requerimiento urgente, entendiendo por tales aquellos en los que un retraso en el suministro de la sangre o componentes sanguíneos pueda comprometer la vida del paciente. El médico responsable del enfermo deberá en tal caso justificar la urgencia de la transfusión por escrito.

${ }^{77}$ Por «aplicación» se entiende «cualquier actividad que implique el uso de células o tejidos en un receptor humano y/o en aplicaciones extracorporales (se engloban las actividades de implantar, infundir, injertar, aplicar o trasplantar)» [art. 2.1.b) Real Decreto 1301/2006]. 


\subsection{El almacenamiento de materiales biológicos con fines terapéuticos (I): bancos de sangre y tejidos}

Es normal que los materiales biológicos que se obtienen con fines terapéuticos no vayan a utilizarse de forma inmediata tras su obtención. Esto no sucede en relación con los órganos, cuyo trasplante al receptor debe realizarse en un plazo de tiempo muy corto desde su extracción ${ }^{78}$, pero sí acontece con otros materiales biológicos como los tejidos o la sangre, los cuales pueden almacenarse tras su obtención por largos periodos de tiempo, con la intención de ser utilizados en el propio sujeto fuente (autotrasplante) o para ser utilizados por un tercero (heterotrasplante). Estos almacenes de materiales biológicos están regulados de una forma muy minuciosa en cada una de las normas específicas.

El Real Decreto 1301/2006 regula todo lo relativo al almacenamiento de células y tejidos humanos, así como de los productos elaborados derivados de ellos, cuando están destinados a ser aplicados en el ser humano. Así, esta norma recoge en su art. 2.1.n lo que debe entenderse por «establecimiento de tejidos», que queda definido en los siguientes términos: «banco de tejidos, unidad de un hospital o cualquier otro centro donde se lleven a cabo actividades de procesamiento, preservación, almacenamiento o distribución de células y tejidos humanos después de su obtención y hasta su utilización o aplicación en humanos. El establecimiento de tejidos también puede estar encargado de la obtención y evaluación de tejidos y células» ${ }^{79}$.

A este respecto, el Capítulo II se ocupa del «procesamiento, almacenamiento y distribución de células y tejidos humanos». En concreto, afirma que el almacenamiento sólo podrá realizarse en aquellos centros o unidades sanitarias debidamente autorizados por la autoridad sanitaria competente siguiendo las bases generales de autorización de centros, servicios y establecimientos sanitarios que establece el Real Decreto 1277/2003, de 10 de octubre, por el que se establecen las bases generales sobre autorización de cen-

${ }^{78}$ El tiempo que puede transcurrir entre la extracción de un órgano del cuerpo del donante y su implantación en el receptor varía dependiendo de las condiciones del donante y del tipo de órgano. Para el riñón lo normal son 24 horas, aunque es posible que funcionen tras conservación en frío hasta 48 horas. Corazón y pulmones sólo pueden mantenerse durante unas seis horas. Hígado y páncreas hasta 12 horas. Los tejidos, sin embargo, tienen un mantenimiento diferente y algunos se pueden congelar y mantener viables durante años; tal es el caso del hueso, ligamentos, cartílago y piel. Las córneas son válidas para trasplante hasta siete días de mantenimiento a $4{ }^{\circ} \mathrm{C}$.

${ }^{79}$ Esta norma ha preferido utilizar el término «establecimiento de tejidos» en vez de «biobanco», denominación que parece querer reservarse para aquel «establecimiento público o privado, sin ánimo de lucro, que acoge una colección de materiales biológicos concebida con fines diagnósticos o de investigación biomédica y organizada como una unidad técnica con criterios de calidad, orden y destino» tal y como se recoge en el art. 3.d del PLIB (la cursiva es nuestra). 
tros, servicios y establecimientos sanitarios, y siempre que se cumpla con los requisitos y condiciones mínimas recogidos en el anexo I.2 de este Real Decreto (art. 14.1 Real Decreto 1301/2006). Por su parte, el art. 17 obliga a designar un responsable técnico para cada establecimiento de tejidos, y enumera sus funciones y responsabilidades.

Por lo que respecta a la sangre, el Real Decreto 1088/2005 también es aplicable al almacenamiento de la sangre humana o sus componentes cuando el destino sea la transfusión (art. 2.b). Además de diversas disposiciones contenidas a lo largo de su articulado, el Anexo VI se ocupa en detalle de las «condiciones de almacenamiento, transporte y distribución de la sangre y los componentes sanguíneos», que obvio enumerar aquí dado su carácter eminentemente técnico.

\subsection{El almacenamiento de materiales biológicos con fines terapéuticos (II): los bancos de cordón umbilical}

En tiempos recientes se ha suscitado un acalorado debate acerca de los beneficios de almacenar sangre proveniente del cordon umbilical con una finalidad terapéutica, en especial cuando dicho material desea conservarse con el propósito de ser utilizado para un eventual trasplante futuro en el sujeto fuente, en el caso de que éste llegara a necesitarlo ${ }^{80}$.

La sangre de cordón umbilical (sangre fetal contenida en la placenta y el cordón umbilical) contiene células troncales que pueden utilizarse para realizar trasplantes a pacientes con una enfermedad congénita o adquirida de la médula ósea, como leucemia aguda, las leucemias crónicas, las inmunodeficiencias (niños burbuja), las aplasias neurales y defectos metabólicos congénitos $^{81}$. Además, estas células pueden conservarse durante largos periodos de tiempo $^{82}$.

A pesar de que el número de progenitores hematopoyéticos contenidos en una unidad de sangre de cordón umbilical es de 7 a 10 veces inferior al

\footnotetext{
${ }^{80} \mathrm{Vid}$. un completo análisis de esta cuestión, LARIOS RisCO, «Donación y uso privativo de la sangre del cordón umbilical: aspectos jurídicos», pp. 181 y ss.

${ }^{81}$ Vid. B. Anthony ARMSON et al., «Umbilical Cord Blood Banking: Implications for Perinatal Care Providers», Journal of Obstetrics and Gynaecology Canada, n. 3 (2005), pp. 264 y ss.

${ }^{82}$ Según algunos estudios, la sangre del cordón umbilical podría crioconservarse durante un periodo de unos diez o quince años manteniendo todo su potencial terapéutico. No obstante, la mayor parte de las muestras que son utilizadas clínicamente no han superado los seis años de crioconservación. Vid. Jennifer GunNING, «Umbilical Cord Blood: Banking and Clinical Application», Revista de Derecho y Genoma Humano, n. ${ }^{\circ} 20$ (2004), pp. 219 y s.; ARMSON et al., «Umbilical Cord Blood Banking: Implications for Perinatal Care Providers», p. 271; Catherine WaLSBY, «Umbilical Cord Blood: From Social Gift to Venture Capital», BioSocieties, n. ${ }^{\circ} 1$ (2006), p. 60.
} 
obtenido de una aspiración de médula ósea, su gran capacidad proliferativa y de implante las hace suficientes para tratar a niños y adultos de bajo peso (en torno a los $50 \mathrm{~kg}$ ), si bien el uso de factores de crecimiento hematopoyético ${ }^{83}$ permite que cada vez un mayor número de adultos pueda someterse a este tratamiento ${ }^{84}$.

Los progenitores de sangre de cordón umbilical presentan ciertas ventajas respecto a los de médula ósea o sangre periférica. En primer lugar, destaca su rápida disponibilidad, al tratarse de unidades fácilmente localizables y transportables. La segunda ventaja es su menor riesgo de rechazo en comparación con el que presenta el trasplante de médula ósea o de sangre periférica $^{85}$. Sin embargo, la menor celularidad hematopoyética a la que hacía referencia anteriormente es también su principal inconveniente, ya que ello supone una recuperación hematopoyética e inmunológica más lenta, así como un mayor riesgo de fallo de implante y la imposibilidad de una segunda donación ${ }^{86}$.

El caso es que en los últimos años han ido apareciendo en diversos países (Alemania, Holanda, Bélgica, Reino Unido, EE. UU., Canadá, entre otros) ${ }^{87}$ bancos de sangre de cordón umbilical de carácter privado que ofrecen a los padres la posibilidad de conservar durante períodos de tiempo indefinidos la sangre de cordón umbilical de los recién nacidos para un hipotético uso personal o familiar si fuese necesario en un futuro.

Estos bancos privados surgen frente a los bancos públicos de sangre de cordón umbilical, existentes en prácticamente todos los países más desarrollados. El banco público se asimila a un banco de donación altruista, es decir, de un donante que pone a disposición de cualquier paciente que lo necesite en todo el mundo su unidad de sangre de cordón. El banco privado, por el

${ }^{83}$ Grupo de proteínas que hacen crecer y madurar las células sanguíneas.

${ }^{84}$ Vid. ARmson et al., «Umbilical Cord Blood Banking: Implications for Perinatal Care Providers», pp. 267 y 269.

${ }^{85}$ Para mejorar las probabilidades de éxito de este tipo de trasplantes, es importante realizar un esfuerzo adicional por obtener muestras selectivas procedentes de pacientes pertenecientes a minorías éticas emergentes en España, para poder atender a toda la población. Vid. Cfr. AA.VV., «Cord Blood Banking for Potential Future Transplantation», Pediatrics, n. ${ }^{\circ} 1$ (2007), p. 168.

Rafael Matesanz, director de la Organización Nacional de Trasplantes, afirmaba en una entrevista que hacen falta determinados fenotipos de grupos del Norte de África o de la América Latina.

${ }^{86}$ Cfr. ARMSON et al., «Umbilical Cord Blood Banking: Implications for Perinatal Care Providers», p. 269; WALSBY, «Umbilical Cord Blood: From Social Gift to Venture Capital», p. 60.

${ }^{87}$ Cfr. Daniel García SAN José, «De vuelta con las células madre: el marco europeo de la clonación humana y los bancos de cordones umbilicales», Revista de Derecho Comunitario Europeo, n. ${ }^{\circ} 24$ (2006), p. 503, con nota 52; ARMSON et al., «Umbilical Cord Blood Banking: Implications for Perinatal Care Providers», p. 268. 
contrario, se asimila a los bancos autólogos o autogénicos en los que las unidades se guardan para su uso potencial de manera exclusiva para el propio donante o para su entorno familiar. La mayor parte de bancos privados tiene un interés lucrativo, mientras que los bancos públicos no tienen ningún ánimo de lucro.

El principal argumento a favor de los bancos privados es que éstos ofrecen al recién nacido una garantía de tratamiento frente a ciertas enfermedades que éste pueda desarrollar durante la infancia o en la edad adulta. Sin embargo, también existen argumentos en contra. Los más relevantes serían los siguientes ${ }^{88}$ :

a) Aún se desconocen las expectativas reales y futuras del uso de estos progenitores, por lo que las promesas que se hacen a los padres para que utilicen estos bancos están, en muchos casos, alejadas de la realidad.

b) Existen alternativas reales al trasplante autogénico. No existe ninguna necesidad conocida de conservar la sangre de cordón umbilical para uso propio. Las diferencias entre la utilización de una unidad totalmente compatible de una unidad de donante y una de uso propio todavía no están establecidas. Además, hay que tener en cuenta que, si se dona ese material a un banco público, muy probablemente esta unidad se mantendrá en el banco durante un largo periodo de tiempo, por lo que existe una alta probabilidad de que ésta todavía esté almacenada si llega a necesitarse.

c) Cabe la posibilidad de que la unidad almacenada no fuera la mejor para tratar al propio donante. Un ejemplo es que unidades de otros donantes tuvieran un número de células mayor que aseguraran una mejor respuesta en el receptor. Por otro lado, respecto de ciertas patologías (como la leucemia o enfermedades congénitas), el uso del material proveniente del propio cordón umbilical podría estar contraindicado, por lo que habría que recurrir en todo caso a la búsqueda de otro cordón diferente del propio. Ello se debe a que las células del cordón almacenado podrían ser portadoras del mismo defecto genético responsable de la enfermedad.

Es decir, que, llegado el caso de que el niño que ha reservado su cordón finalmente precisa de un trasplante de progenitores hematopoyé-

${ }^{88} \mathrm{Vid}$. a este respecto, National Consultative Ethics CommitTeE for HeAlth AND Life SCIENCES (France), Opinion n. ${ }^{\circ} 74$ on Umbilical Cord Blood Banks for Autologous Use or for Research, 12 December 2002; The European Group on Ethics In Science ANd New TeChNOLOGIES to the EuROPEAn COMmission, Opinion on the Ethical Aspects of Umbilical Cord Blood Banking, 16 March 2004; AA.VV., «Cord Blood Banking for Potential Future Transplantation», Pediatrics, n. ${ }^{\circ} 1$ (2007), pp. 166 y ss. 
ticos por sobrevenirle una enfermedad, muy probablemente encontrará otras unidades en el conjunto de los cordones almacenados en los bancos públicos (trasplantes alogénicos) con características mucho más ventajosas para el trasplante que las de su propio cordón.

d) Finalmente, se advierte del riesgo de que la generalización de esta práctica pueda afectar a la donación altruista de unidades para uso no personal o familiar.

Teniendo en cuenta todos estos elementos, el legislador español se ha ocupado de los bancos de cordón umbilical por primera vez de forma expresa en Real Decreto 1301/2006. Esta norma prevé la posibilidad de que existan establecimientos (de carácter privado) entre cuyas actividades figure la preservación de células y/o tejidos para un eventual uso autólogo, esto es, cuando las células y/o tejidos son obtenidos con la finalidad de ser preservados para su aplicación hipotética futura en la misma persona, sin que exista una indicación médica establecida en el momento de la obtención e inicio de la preservación (art. 2.2.c Real Decreto 1301/2006).

En su exposición de motivos, el Real Decreto reconoce que no existe una base científica actual ni respaldo de las instituciones europeas a dicha práctica. Sin embargo, se ha considerado necesario regularla dada la presencia y progresiva implantación de este tipo de establecimientos en los países de nuestro entorno. Este Real Decreto establece las condiciones que deben cumplir tales establecimientos.

Así pues, la ley autoriza la creación de bancos privados de cordón umbilical ${ }^{89}$. No obstante, impone una condición de gran relevancia, a fin de hacer compatible la libertad de empresa y de prestación de servicios con el principio de altruismo que ha imperado tradicionalmente en nuestro país en relación con la donación y trasplante de órganos y tejidos. De acuerdo con el art. 7.2.II Real Decreto 1301/2006, «en el supuesto de uso autólogo eventual, el contenido de la información facilitada con anterioridad a la obtención deberá incluir (...) la indicación de que las células y tejidos así obtenidos estarán a disposición para su uso alogénico en otros pacientes en el caso de existir indicación terapéutica; la información actual, veraz y completa sobre

${ }^{89} \mathrm{Si}$ bien éstos tienen importantes restricciones, pues, de acuerdo con lo establecido en el art. 3.5 Real Decreto 1301/2006, sus actividades no tendrán carácter lucrativo y exclusivamente podrán repercutirse los costes efectivos de los servicios prestados por el desarrollo de las actividades autorizadas. Cfr. LARIOS RISCO, «Donación y uso privativo de la sangre del cordón umbilical: aspectos jurídicos», pp. 206 y s.

A raíz de esta normativa, las Autoridades Sanitarias españolas ya han autorizado la puesta en marcha en nuestro país de algún banco privado de sangre de cordón umbilical (VidaCord, Secuvita). El coste total del servicio es de unos $2000 €$, lo cual incluye el almacenamiento del material biológico por un periodo de veinte años. Si la muestra fuera requerida antes de dicho término, se restituye a las familias el coste proporcional correspondiente a los años restantes de contrato. 
el estado de los conocimientos científicos respecto de los usos terapéuticos o de investigación; las condiciones de procesamiento y almacenamiento en los establecimientos autorizados; y cualquier otra cuestión relacionada con la utilidad terapéutica de la obtención de células y tejidos sin indicación médica establecida en el momento de la obtención e inicio de la preservación». Igualmente, según el art. 27.2 in fine Real Decreto 1301/2006, «en el caso de que se realicen actividades de procesamiento para usos autólogos eventuales de los que no hay indicación médica establecida actual, las células y tejidos así procesados estarán disponibles para su aplicación alogénica (...)».

De esta manera, esta norma prevé que los materiales biológicos que se han depositado en un banco privado puedan ser empleadas, en cualquier caso, para realizar un trasplante alogénico, siempre que ello sea necesario por razones terapéuticas. Por esta razón, «los establecimientos de tejidos que preserven células y tejidos para usos autólogos eventuales vienen obligados además a suscribir un seguro que cubra los costes de procesamiento, preservación y almacenamiento para el supuesto de que se produzca la cesión o el envío de esas células y tejidos a otro establecimiento, centro o unidad sanitaria para usos alogénicos en procedimientos terapéuticos con indicaciones médicas establecidas en receptores adecuados (...)» (art. 15.4 Real Decreto 1301/2006).

No obstante lo anterior, en casos excepcionales médicamente indicados, sí que es posible la conservación de sangre de cordón umbilical (u otro tipo de células o tejidos) para su uso posterior por parte del sujeto fuente o un miembro de la familia biológica ${ }^{90}$, de tal forma que tales muestras no estarían disponibles para un eventual trasplante alogénico. Esta posibilidad está condicionada, tal y como se señala en el art. 27.2 Real Decreto 1301/2006, a que la aplicación autóloga esté encuadrada en el marco de un procedimiento terapéutico de eficacia demostrada en indicaciones médicas establecidas. Este almacenamiento podrá llevarse a cabo en cualquier banco público sin ningún coste económico para la familia.

Por lo que respecta a la información y el consentimiento necesarios para proceder a la recogida y almacenamiento de esta tipología de materiales biológicos, cabe hacer una serie de consideraciones ${ }^{91}$ :

a) La información debe ser especialmente rigurosa y completa, a fin de evitar ofrecimientos de servicios engañosos. En concreto, habrá que informar a los potenciales clientes de estos bancos de cordón umbilical, de la incertidumbre científica existente sobre su utilidad real, así como del resto de eventualidades a las que hacíamos referencia más arriba (por ejemplo, que el cordón umbilical propio puede no ser el más adecuado en el caso de que fuera necesario un trasplante).

${ }^{90}$ Cfr. AA.VV., «Cord Blood Banking for Potential Future Transplantation», p. 167.

${ }^{91}$ Cfr. AA.VV., «Cord Blood Banking for Potential Future Transplantation», pp. 166 y ss.; ARMsOn et al., «Umbilical Cord Blood Banking: Implications for Perinatal Care Providers», pp. 272 y s. 
A este respecto, el legislador se ha ocupado expresamente de la publicidad en relación con la donación u obtención de tejidos y células humanos. Así, en su art. 4.3. dispone que «la existencia y/o persistencia de publicidad y promoción falsa, engañosa o tendenciosa será incompatible con la autorización de actividades de obtención, preservación, procesamiento, distribución o aplicación de células y tejidos en España por parte del centro, institución, unidad o establecimiento de tejidos que haya emitido dicha publicidad o tenga relaciones contractuales con la institución que haya emitido la publicidad. En particular, se entenderá que existe publicidad engañosa en el caso de los establecimientos, centros, unidades e instituciones cuya publicidad induzca a error sobre la utilidad real de la obtención, procesamiento y preservación de células y tejidos humanos para usos autólogos eventuales, de acuerdo con los conocimientos y experiencia disponibles».

b) La sangre procedente del cordón umbilical será sometida a determinados análisis antes de ser incorporadas al banco de sangre del cordón umbilical, tal y como sucede con otro tipo de materiales biológicos. Por ello, la información que se ofrece a los padres del recién nacido debe abarcar también a dicho extremo, comunicando la tipología de análisis que van a realizarse, así como el hecho que éstos serán informados de los resultados, si fueran anormales.

c) Si se ha recogido sangre del cordón umbilical de un niño recién nacido que posteriormente desarrolla una neoplasia maligna, o una enfermedad de carácter genético o inmunológico, los padres deberían comunicarlo al banco de cordón umbilical, de tal modo que dicha unidad no sea utilizada para trasplante. En todo caso, habría que establecer un sistema eficaz de notificación de tales eventualidades.

d) El consentimiento debería obtenerse por escrito antes de dar comienzo a las labores del parto y a la recogida del material biológico. Algunos autores añaden, además, que el consentimiento debería ser confirmado tras el parto ${ }^{92}$. Además, habrá que tener en cuenta la especial vulnerabilidad emocional de la madre en tales momentos. Esto hace que la información deba transmitirse de forma especialmente clara y objetiva. También se informará de que la recogida del material biológico no ser realizará si ello pudiera poner en peligro la integridad de la mujer o del bebé ${ }^{93}$.

\footnotetext{
${ }^{92}$ ARmson et al., «Umbilical Cord Blood Banking: Implications for Perinatal Care Providers», p. 272.

${ }^{93}$ A este respecto, el punto 2.2.I in fine del Anexo II del Real Decreto 1301/2006, establece que «en el caso de la donación de sangre de cordón umbilical o membrana amniótica, no deberá haber interferencia ni compromiso con el cuidado y la seguridad de la madre o el recién nacido».
} 
e) Puede suceder que exista un conflicto de intereses cuando la persona o personas (personal sanitario o no) que informa sobre el posible destino de las células del cordón umbilical, tengan un interés en captar pacientes dado que con ello obtendrían un beneficio económico (por ejemplo, si tienen una participación económica en los beneficios del banco de células de cordón umbilical, o si recibe una comisión por cada paciente $)^{94}$. Por ello, debería exigirse que en el documento de consentimiento, además de constar la información general sobre la utilidad del material biológico en cuestión, se haga constar expresamente el nombre de los sujetos que participan en la transmisión de la información, obtención del consentimiento y gestión de las muestras, declarando si van a obtener un beneficio económico con dicha actuación, o si existiera cualquier otro tipo de conflicto de intereses.

Además, hay que tener en cuenta que en aquellos casos en los que se desee obtener sangre del cordón umbilical para destinarla a bancos privados, el parto deberá producirse en un centro sanitario privado que haya firmado un convenio con el banco privado correspondiente, pues la normativa vigente no autoriza a los centros sanitarios públicos a recoger el mencionado material biológico y remitirlo al banco privado, incluso si los padres estuvieran dispuestos abonar el coste de la operación ${ }^{95}$.

Por último, cabe señalar que la Comunidad de Madrid ha presentado ante el Tribunal Constitucional un recurso de inconstitucionalidad contra el Real Decreto 1301/2006 por entender que éste regula materias que son competencia suya ${ }^{96}$, en concreto lo relativo a los requisitos para la autorización y acreditación de los bancos de sangre de cordón umbilical. La Comunidad de Madrid había aprobado con anterioridad a este Real Decreto, el Decreto 28/2006, de 23 de marzo, por el que se regula la constitución y régimen de funcionamiento de los depósitos de sangre procedentes de cordón umbilical, y la subsiguiente Orden 837/2006, de 6 de abril, de la Consejería de Sanidad y Consumo, por la que se regulan los requisitos necesarios para la autorización y acreditación de los depósitos de sangre procedente de cordón umbilical en el ámbito territorial de la Comunidad de Madrid, cuyo objeto es, según dispone su art. $1, \ll(\ldots)$ regular los requisitos específicos que deben reunir los depósitos de sangre procedente de cordón umbilical para la obtención de la correspondiente autorización y acreditación sanitaria, en el ámbito territorial de la Comunidad de Madrid». Sin embargo, este Decreto ha sido suspendi-

${ }^{94}$ Cfr. Jennifer GunNing, «Umbilical Cord Blood: Banking and Clinical Application», Revista de Derecho y Genoma Humano, n. 20 (2004), p. 219.

${ }^{95}$ Cfr. LARIOS RISCO, «Donación y uso privativo de la sangre del cordón umbilical: aspectos jurídicos», pp. 199 y s.

${ }^{96}$ BOE de 15 de marzo de 2007. 
do cautelarmente por la sala de lo contencioso administrativo del Tribunal Superior de Justicia de Madrid, a instancias de un recurso presentado por la Abogacía del Estado en representación del Ministerio de Sanidad ${ }^{97}$.

En cualquier caso, una vez aprobado el Real Decreto, la decisión sobre el fondo del asunto pierde su importancia, ya que al ser este posterior a la norma autonómica madrileña y tener carácter de legislación básica, desplazaría a la Orden de la Comunidad de Madrid y será de aplicación preferente $^{98}$, a expensas de lo que resuelva el Tribunal Constitucional en relación con el conflicto positivo de competencias referido.

97 Vid. más detalladamente, sobre el conflicto surgido entre el gobierno central y la Comunidad de Madrid, LARIOS RISCO, «Donación y uso privativo de la sangre del cordón umbilical: aspectos jurídicos», pp. 203 y ss.

${ }^{98}$ Cfr. Sergio Romeo Malanda, «Efectos jurídicos de la contravención por parte de las Comunidades autónomas de la legislación básica estatal en materia de derechos de los pacientes», en José María Vidal Beltrán/Miguel Ángel García Herrera (coords.), El Estado Autonómico: integración, solidaridad, diversidad, Volumen II, Colex-INAP, Madrid, 2005, pp. 367 y ss. 